\title{
A contribution to the genera Plectonotum Gorham and Hyponotum Wittmer, with the description of sixteen new species from Peru (Coleoptera, Cantharidae)
}

\author{
Robert Constantin ${ }^{1}$ \\ ${ }^{1}$ Independent researcher. Saint-Lô, France. ORCID: http://orcid.org/0000-0003-1671-7412. E-mail: rconstantin50@gmail.com
}

\begin{abstract}
Sixteen species of Peruvian Dysmorphocerinae (Cantharidae) are described as new (regions in parenthesis): Hyponotum macrocephalum sp. nov. (Huanuco); H. succhabamba sp. nov. (Cajamarca); Plectonotum altomayo sp. nov. (Amazonas); P. amazonas sp. nov. (Amazonas); P. bicoloricolle sp. nov. (Huanuco); P. carpish sp. nov. (Huanuco); P. celendin sp. nov. (Cajamarca); P. costae sp. nov. (Cajamarca); P. huariaca sp. nov. (Pasco and Huanuco); P. huascaran sp. nov. (Ancash); P. huertoae sp. nov. (Cajamarca); P. leymebamba sp. nov. (Amazonas); P. luteipes sp. nov. (Amazonas); P. oxapampa sp. nov. (Pasco); P. rubrithorax sp. nov. (Huanuco); P. shipasbamba sp. nov. (Amazonas). A lectotype is designated for Plectonotum longissimum (Pic, 1927) for which a redescription is provided. Plectonotum ruficolle Wittmer, 1988, homonym of Plectonotum ruficolle Pic, 1926, is renamed as Plectonotum neoruficolle nom. nov. New keys are proposed in English and Spanish for the identification of the Peruvian species of the genus Plectonotum and the South American species of the genus Hyponotum Wittmer, together with macrophotographs of habitus, details of pronotum, male genitalia and a cartographic representation of their distribution.
\end{abstract}

Key-Words. Neotropical; Soldier-beetles; Dysmorphocerinae; Neotropical region; Taxonomy.

\section{INTRODUCTION}

The subfamily Dysmorphocerinae (Cantharidae) was introduced by Brancucci (1980) based, among other characters, on the mandibles apically toothed, the last maxillary palpomere usually not pointed, the male sternite IX visible and elongate and a peculiar genital morphology. The subfamily encompasses genera distributed in Neotropical region and also in southern Africa, Australia (including Tasmania), New Guinea and New Zealand. With about 250 known species, it remains a relative small group. A key to distinguish the Neotropical genera of the subfamily Dysmorphocerinae was given in a previous publication (Constantin, 2008).

Besides the initial descriptions by Gorham $(1885,1891)$ and some laconic others by Pic, most of the taxonomic work was produced by Wittmer, illustrated with meaningful drawings. In South America, the genus Plectonotum Gorham is the most species-rich, with nearly fifty valid species. A previous contribution to the Plectonotum of Ecuador revealed an important number of new species in the Andes mountains (Constantin, 2008, 2010). Similarly, new survey works in Peru brought to light fourteen new species of
Plectonotum, here described. Besides, two new species of Hyponotum Wittmer were discovered in north Peru. The genus was previously known only from Chile, south of Santiago, and in Argentina southern Andes. Given the large number of isolated descriptions, a key to the South American species of the genus Hyponotum is herein proposed.

\section{MATERIAL AND METHODS}

The first specimens examined were collected during personal fieldworks. Comparison with type material and other specimens preserved in the museum of Paris (MNHN, collection of Maurice Pic), the museum of Basel (NHMB, collection of Walter Wittmer, including the collection of Richard Hicker) allowed to re-check most of the specific characters and to confirm several species as new to science. Additional specimens were borrowed from the museum of Lima (MUSM). Photographs of habitus were obtained with a digital reflex camera adapted on a Leica stereomicroscope MZ12.5 and the focus stacks assembled with Helicon Focus software. Microphotographs of genitalia (glued on the tip of pointed board) were taken with a compound microscope utilising a 10× ob- 
jective combined with episcopic illumination and series of $4 \mu \mathrm{m}$ spaced image layers assembled with the same software. The distribution map was prepared with Data Fauna Flora and Carto Fauna Flora (Barbier et al., 2000).

\section{Abbreviations of the institutions in which the stud- ied material is deposited: CAS: California Academy of Sciences, San Francisco, USA; CCo: author's collection, Robert Constantin, Saint-Lô, France; MNHN: Muséum na- tional d'Histoire naturelle, Paris, France; MUSM: Museo de Historia Natural, Universidad Nacional Mayor de San Marcos, Lima, Peru; NHMB: Naturhistorisches Museum Basel, Basel, Switzerland.}

Abbreviations for measurement indices: $T L=$ total length from clypeus to elytral apex; $A L=$ antennal length, fully extended; HW = head width including the eyes; IOW = interocular width; IAW = width between the antennal sockets; $\mathrm{OL}=$ greatest length of the eye in lateral view; $\mathrm{PL}=$ pronotum length; $\mathrm{PW}=$ pronotum width; $\mathrm{EL}=$ elytron length from humerus to apex; EW = elytra combined width at the base; al to $\mathrm{aXI}=$ antennomeres I to XI.

\section{RESULTS}

\section{The genus Plectonotum Gorham, 1885}

The genus Plectonotum Gorham, 1885, was erected for P. labiale Gorham, 1885, based on the singular lateral bead of the pronotum. Among the Neotropical genera of Dysmorphocerinae, this genus is also characterized by: small size, usually under $6.0 \mathrm{~mm}$; elongate and fee- bly convex body shape; slender antennae without deformed antennomeres; elytra without foveate punctations aligned in striae; apical margin of pygidium with two conical lateral tubercles variably developed; peculiar morphology of the male genitalia.

The aedeagus (Figs. 116-118) displays the characters of the Dysmorphocerinae, derived from the trilobed Elateroidea type: tegmen with a distinct phallobase (phb), and with the apical part projecting backwards in two lateral lobes or parameres (Ilb), lateral lobes ventrally attached to a pair of joined apico-ventral apophysis (ava), median lobe ( $\mathrm{mlb}$ ), basally developed, and sheathed between two thin lateral sclerites (Isc), lamellar, sagittal oriented, tapered, internal sac usually with a sclerotized apical part (msi), sheathed between the lamina of the two lateral sclerites.

The members of the genus Plectonotum are distributed all over the Neotropical region between Panama and Chile with nearly fifty valid species. The first identification key for species was written by Pic (1911). Later, one additional Plectonotum species was described from Brazil (Wittmer, 1967). Further, a key was given for the species occurring in Bolivia and south Peru (Wittmer, 1988). The species of Ecuador were keyed in contributions to the Plectonotum of Ecuador (Constantin, 2008, 2010). From Peru, only six species were previously known (Constantin \& Chaboo, 2016): Plectonotum howdeni Wittmer, 1988, P. inca Wittmer, 1988, P. longissimum (Pic, 1927), P. martinezi Wittmer, 1988, P. peruanum Wittmer, 1967, and P. ruficolle Wittmer, 1988.

Fourteen new species are described below and a new key is proposed here for separating the twenty species currently known from Peru.

\section{Key to the Peruvian species of Plectonotum}

1. Length over $6.0 \mathrm{~mm}$. Body narrow, either uniform black or with pale yellow patches in pronotum and elytra. Head and pronotum thinly and coarsely punctate. Elytra subseriately punctate (Fig. 13)

P. longissimum (Pic, 1927)

- Length under $5.0 \mathrm{~mm}$. Other characters different.

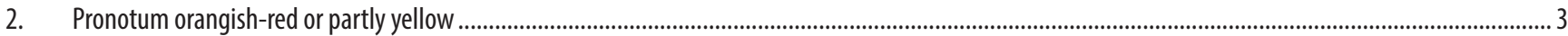

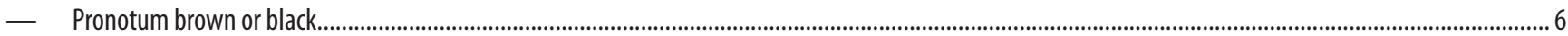

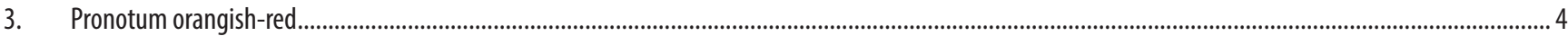

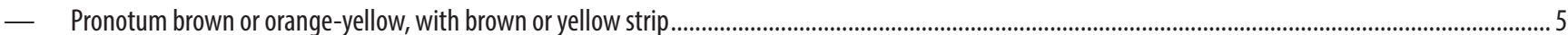

4. Pronotal bead narrow (Fig. 42). Frons depressed between the eyes... P. rubrithorax sp. nov.

- Pronotal bead wide (Fig. 39). Frons feebly convex between the eyes P. neoruficolle nom. nov.

5. Pronotum orange-yellow with a wide median brown strip from front to rear edges (Fig. 30). P. howdeni Wittmer, 1988

- Pronotum brown with a wide transverse yellow strip on the basal third (Fig. 26). P. bicoloricolle sp. nov.

6. Legs partly brown, the femora and base of tibiae yellow. Clypeus yellow ...

- Legs brown or black. Clypeus usually dark

7. Lateral margins of the pronotum straight in the middle part, the bead short and narrow. Antennae brownish yellow. Length 3.8 mm .....P. inca Wittmer, 1988

- Lateral margins of the pronotum regularly rounded, the bead narrow. Antennae brown, the first two antennomeres partly yellow ...

8. Head and pronotum thinly punctate (Fig. 40). Pronotal bead narrow, long, reaching the front corners. Length $3.6-4.7 \mathrm{~mm}$...................... P. oxapampa sp. nov.

- Head and pronotum not punctate (Fig. 37). Pronotal bead thicker, narrowed before the front corners. Length $3.6 \mathrm{~mm}$.................................P. luteipes sp. nov.

9. Head black, the clypeus and frons before the antennal sockets entirely or partly yellow ............................................................................................... 10

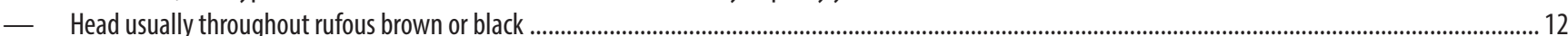

10. Pronotum glossy, without visible punctation (Fig. 38). Pronotal bead short and narrow .............................................................. P. martinezi Wittmer, 1988

- Pronotum feebly shiny, thinly punctate 11

11. Lateral margins of the pronotum nearly straight, slightly convergent (Fig. 43). Pronotal bead narrow, not basally wider. Males: antennae as long as the elytra. Length 3.6-4.1 mm P. shipasbamba sp. nov. 
Lateral margins of the pronotum slightly rounded and convergent (Fig. 24). Pronotal bead apically narrow, basally wider. Males: antennae shorter than the elytra. Head and pronotum often microreticulate. Females: epipleura pale yellow .. P. altomayo sp. nov.

12. Elytra strongly punctate 13

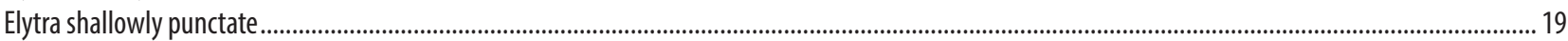

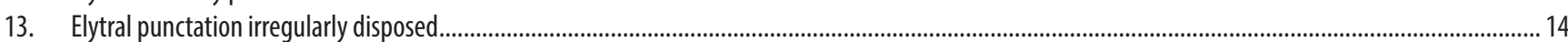

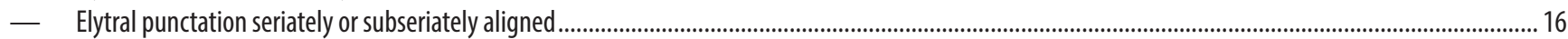

14. Pronotal bead long and narrow (Fig. 31). Elytra rather short, 2.4 times longer than combined width at the base. Female apterous. Length under $3.0 \mathrm{~mm}$.......

P. huariaca sp. nov.

- Pronotal bead shorter and wider. Length over $3.0 \mathrm{~mm}$

P. huertoae sp. nov.

15. Pronotal bead narrowing apically (Fig. 33). Head uniform black P. leymebamba sp. nov.

Pronotal bead as wide apically as basally (Fig. 35). Clypeus rufous or brown. Length 3.9-4.5 mm ength 3.0-3.7 mm..

... celendin sp. nov.

- Pronotum not wider than base of elytra.

... 17

17. Pronotal bead rounded, medially dilated, narrowing apically and basally (Fig. 29)... P. costae sp. nov.

- Pronotal bead straight and narrow

18. Pronotal disc medially depressed, densely and strongly punctate (Fig. 25). Elytra elongate. Length over $4.0 \mathrm{~mm}$.

- Pronotal disc convex, thinly punctate (Fig. 32). Elytra shorter. Length 3.0-4.1 mm. 18

19. Pronotal disc convex, microreticulate, thinly and densely punctate (Fig. 41). Head, pronotum and elytra black. Males: antennae shorter than the combined length of pronotum and elytra ..P. peruanum Wittmer, 1967

- Pronotal disc feebly convex, glossy, thinly and less densely punctate (Fig. 27). Head black. Pronotum and elytra reddish brown. Males: antennae elongate, as long as the combined length of pronotum and elytra ...... P. carpish sp. nov.

\section{DESCRIPTION OF NEW SPECIES}

\section{Plectonotum altomayo sp. nov. (Figs. 1, 24, 47-48, 93, 119)}

Type material: Holotype ơ (MUSM): Peru, Amazonas, provincia de Bongará, $1 \mathrm{~km}$ East of Abra Patricia, forest edge, $05^{\circ} 40^{\prime} 39^{\prime \prime} \mathrm{S}, 77^{\circ} 46^{\prime} 25^{\prime \prime} \mathrm{W}$, alt. 1,970 m, 11.V.2018, leg. R. Constantin. Paratypes: $20^{\prime \prime}, 5 \%$, same locality and same date of holotype. Holotype and three female paratypes deposited in the collection of the MUSM, other paratypes preserved in author's collection (CCo).

Description: Holotype. Length $3.6 \mathrm{~mm}$. Head black, the clypeus and the genae orange yellow in front of the antennal sockets. Antennae black, the first two antennomeres yellow with brown dorsal patches, the third brownish yellow. Mandibles yellow. Labial and maxillary palpi black, their first joint yellow. Legs black, the front tibiae reddish brown. Prothorax black. Elytra black, a narrow pale-yellow line along the lateral margins and the epipleura. Abdomen black. Head 0.8 times as wide as pronotum, the clypeus triangularly protruding. Eyes developed, bulging, the interocular space 0.57 times as wide as the head. Frons broad, flattened between the eyes. Temples short, narrowing backwards. Cephalic surface smooth, superficially microreticulate, thinly punctate, with thin whitish setae. Antennae two thirds as long as the body, the first two antennomeres smooth, the following parallel sided, dull, covered with thin brown setae. Pronotum (Fig. 24) 1.5 times wider than long, transversally convex. Front edge medially flat and laterally arched, rear edge angular, lateral edge rounded with a long narrow bead and a small emargination in front of the basal corners. Pronotal surface shiny, markedly punctate, with punctations as wide as the intervals. Elytra 2.8 times longer than combined width at the base, strongly and subseriately punctate, covered with long, thin, recumbent pale-yellow setae. Aedeagus (Figs. 47-48, 93): tegmen with apex of the lateral lobes dilated with triangular internal callus; the pair of apico-ventral apophyses narrow and recurved, as also the long lateral sclerites and the tip of the median lobe.

Dimensions of the holotype: $T L=3.6 \mathrm{~mm} ; A L=2.4 \mathrm{~mm}$; $\mathrm{HW}=0.78 \mathrm{~mm} ; \mathrm{IOW}=0.45 \mathrm{~mm} ; \mathrm{OL}=0.25 \mathrm{~mm} ;$ IAW $=0.19 \mathrm{~mm} ; \mathrm{PL}=0.63 \mathrm{~mm} ; \mathrm{PW}=0.94 \mathrm{~mm} ;$ $\mathrm{EL}=2.65 \mathrm{~mm} ; \mathrm{EW}=0.93 \mathrm{~mm}$. Length of the antennomeres, in $\mathrm{mm}$ : $a l=0.27$; all $=0.12$; all $=0.20$; $a \mathrm{IV}=0.24$; $a V=0.25 ; a V I=0.25 ; a V I I=0.23 ; a V I I I=0.23 ; a I X=0.20 ;$ $a X=0.19 ; a X I=0.22$. Paratypes $o^{\text {: }}$ length $3.9 \mathrm{~mm}$.

Paratypes : Differ from males by the less convex eyes, shorter antennae, and pronotum narrowing anteriorly. Dimensions of one paratype $9 . \mathrm{TL}=4.3 \mathrm{~mm} ; \mathrm{AL}=2.7 \mathrm{~mm}$; $\mathrm{HW}=0.73 \mathrm{~mm} ; \mathrm{IOW}=0.48 \mathrm{~mm} ; \mathrm{OL}=0.23 \mathrm{~mm} ;$ IAW $=0.22 \mathrm{~mm} ; \mathrm{PL}=0.72 \mathrm{~mm} ; \mathrm{PW}=1.13 \mathrm{~mm}$; $\mathrm{EL}=3.3 \mathrm{~mm} ; \mathrm{EW}=1.12 \mathrm{~mm}$. Other paratypes \%: length 4.2-4.7 $\mathrm{mm}$, mean $4.35 \mathrm{~mm}$.

Variability: The two male paratypes have uniform black elytra, and one of them has dull, markedly microreticulate cephalic and pronotal surface.

Differential diagnosis: Plectonotum altomayo sp. nov., is similar to P. oxapampa sp. nov., and P. bicoloricolle sp. nov., with similar pronotal bead. It differs from these latter by the mostly black colour pattern, thicker antennae, subseriate elytral punctation, and the aedeagus shape.

Etymology: Specific name refers to "Bosque de Protección Alto Mayo", close to the Área de Conservación 
Privada "Abra Patricia" on the road to Paso Pardo de Miguel. Noun in apposition.

Natural history: Collected by beating shrubs and trees, mainly Melastomataceae close to the genus Miconia, on the edge of the mountain forest, whose foliage was still wet in the morning.

\section{Plectonotum amazonas sp. nov.} (Figs. 2, 25, 49-50, 94, 116-118, 119)

Type material: Holotype $\sigma^{\pi}$ (MUSM): Peru, Amazonas, provincia de Chachapoyas, Balsas 53 km E, Abra Calla

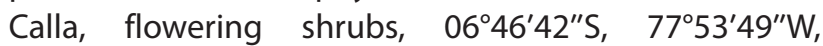
alt. 3,281 m, 07.V.2018, leg. R. Constantin. Paratypes: $80^{\circ}, 79$, same locality and same date as holotype; - 330", 13ㅇ, provincia de Chachapoyas, Balsas 55 km E, Abra Calla Calla, flowering shrubs, $06^{\circ} 45^{\prime} 36^{\prime \prime} \mathrm{S}, 77^{\circ} 53^{\prime} 29^{\prime \prime} \mathrm{W}$, alt. 3,427 m, 08.V.2018, leg. R. Constantin; - 30", provincia de Chachapoyas, Leymebamba $10 \mathrm{~km} \mathrm{SW}$, flowering shrubs, $06^{\circ} 43^{\prime} 30^{\prime \prime} \mathrm{S}, 77^{\circ} 50^{\prime} 29^{\prime \prime} \mathrm{W}$, alt. 2,923 m, 08.V.2018, R. Constantin. Holotype and twenty paratypes deposited in the collection of the MUSM, other paratypes preserved in author's collection (CCO).

Description: Holotype. Length $3.9 \mathrm{~mm}$. Head, prothorax, elytra, abdomen, antennae and legs black. Mandibles brownish yellow. Head 0.77 times as wide as the pronotum. Clypeus feebly prominent, rounded. Eyes short, bulging, the interocular space 0.62 times as wide as the head. Frons concave between the antennal sockets, flat behind with two small oblique ridges. Cephalic surface smooth, strongly punctate, the punctations as wide as the intervals, with yellowish setae. Antennae 0.8 times as long as the body, the antennomeres subparallel sided, alutaceous, covered with short erected brownish setae. Pronotum (Fig. 25) 1.5 times wider than long, slightly transversally convex. Front edge arched and raised; basal edges weakly arched, bordered by a shallow groove; lateral edges straight, converging frontwards with a long, narrow bead and a small emargination in front of the obtuse angled basal corners. Pronotal surface smooth, strongly punctate, the punctations twice as wide as the intervals, covered with rather long yellowish setae. Elytra 3 times longer than their combined width at the base, not costate, with a subseriate punctation, with punctations twice wider than the intervals, seriately disposed on the four internal lines, more irregular externally, covered with long yellowish setae obliquely backwards directed. Abdomen: Tergite IX with apical edge triangular, thinly incised in the middle; sternite IX wider than long, the apical edge triangularly arched. Aedeagus: tegmen with apex of the lateral lobes with convex internal callus, apically rounded and covered with long bristles; apico-ventral apophyses narrow and recurved; lateral sclerites narrow with sharp tooth at mid-length; tip of the median lobe with a narrow triangular projection.
Dimensions of the holotype: $T L=3.9 \mathrm{~mm} ; A L=3.1 \mathrm{~mm}$; $\mathrm{HW}=0.79 \mathrm{~mm} ; \mathrm{IOW}=0.5 \mathrm{~mm} ; \mathrm{OL}=0.23 \mathrm{~mm} ; \mathrm{IAW}=0.17 \mathrm{~mm}$; $\mathrm{PL}=0.67 \mathrm{~mm} ; \mathrm{PW}=1.02 \mathrm{~mm} ; \mathrm{EL}=3.05 \mathrm{~mm} ; \mathrm{EW}=1.0 \mathrm{~mm}$. Length of the antennomeres, in $\mathrm{mm}: \mathrm{al}=0.34$; all $=0.12$; all = 0.28; $a \mathrm{IV}=0.34 ; a \mathrm{~V}=0.34 ; a V I=0.35 \times 0.08$ (width); $a V I I=0.36 ; a V I I I=0.38 ; a I X=0.30 ; a X=0.27 ; a X I=0.31$. Paratypes ox: length 3.7-4.5 mm, mean $4.0 \mathrm{~mm}$.

Paratypes 9 : Differ from males in the smaller eyes, the shorter antennae, and the wider pronotum. Sternite VIII short and wide, the apical edge deeply incised in the middle. Dimensions of a medium sized specimen $\%$. $\mathrm{TL}=4.3 \mathrm{~mm} ; \mathrm{AL}=2.25 \mathrm{~mm} ; \mathrm{HW}=0.75 \mathrm{~mm} ; \mathrm{IOW}=0.52 \mathrm{~mm}$; $\mathrm{OL}=0.22 \mathrm{~mm} ; \mathrm{IAW}=0.22 \mathrm{~mm} ; \mathrm{PL}=0.76 \mathrm{~mm}$; $\mathrm{PW}=1.21 \mathrm{~mm} ; \mathrm{EL}=3.35 \mathrm{~mm} ; \mathrm{EW}=1.15 \mathrm{~mm}$. Paratypes o: length 4.0-4.6 mm, mean $4.3 \mathrm{~mm}$.

Differential diagnosis: Plectonotum amazonas sp. nov., is similar to $P$. huascaran sp. nov., by habitus, colour pattern and pronotal shape. It differs from the latter in the bigger size, the strong pronotal punctations, the less regularly seriate elytral punctation and the aedeagus.

Etymology: Specific epithet is related to the regional name of the type locality. Noun in apposition.

Natural history: Collected by beating the foliage of the shrubs along the access road to Abra Calla Calla between Celendin and Leymebamba.

\section{Plectonotum bicoloricolle sp. nov. (Figs. 3, 26, 51-52, 95, 119)}

Type material: Holotype ơ (MUSM): Peru, Huanuco, provincia de Leoncio Prado, 40 km NE de Tingo Maria, Abra

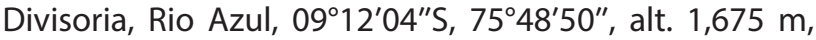
31.III.2015, leg. R. Constantin \& L. Huamán Cuespán. Paratypes: $10^{\circ}, 19$, same of the holotype; - 19, same locality, 04.IV.2015, leg. R. Constantin; - 19, Peru, Cusco, provincia de Quispicanchi, Marcapata 35 km N, Capire, $13^{\circ} 26^{\prime} 01^{\prime \prime} \mathrm{S}, 70^{\circ} 54^{\prime} 18^{\prime \prime} \mathrm{W}$, alt. 1,299 m, M. Rodriguez \& L. Pérez leg. Holotype and two female paratypes deposited in the collection of the MUSM, two paratypes preserved in author's collection (CCO).

Description: Holotype. Length $3.8 \mathrm{~mm}$. Head yellow anteriorly, black behind the antennal sockets. Antennae black, the ventral face of the first two antennomeres yellow, the third brownish yellow. Elytra brown. Legs yellow, the apical half of metatibiae and the tarsi brown. Abdomen brown, the last visible sternite yellow. Head 0.9 times as wide as pronotum, the clypeus protruding. Eyes developed, bulging, the interocular space as wide as the half of head. Frons flattened between the eyes. Temples short, strongly narrowing backwards. Cephalic surface bright, thinly punctate, with thin yellowish setae. Antennae as long as the body, the first two antennomeres smooth, the following parallel sided, slightly warty, covered with thin brown setae. Pronotum 1.4 times wider 
than long, transversally convex. Front edge arched, rear edge angular, lateral edge rounded with a narrow bead and a small emargination in front of the basal corners. Pronotal surface shiny, thinly punctate, with punctations 1.5 times smaller than intervals. Elytra 2.7 times longer than combined width at the base, markedly and irregularly punctate, covered with long, thin, recumbent yellow setae. Aedeagus: tegmen with lateral lobes strongly reduced and notched posteriorly, dorsally extended; the pair of apico-ventral apophyses dorsally recurved as also the long lateral sclerites; median lobe broad and short.

Dimensions of the holotype: $T L=3.8 \mathrm{~mm} ; A L=3.8 \mathrm{~mm}$; $\mathrm{HW}=0.84 \mathrm{~mm} ; \mathrm{IOW}=0.39 \mathrm{~mm} ; \mathrm{OL}=0.34 \mathrm{~mm} ;$ $I A W=0.14 \mathrm{~mm} ; \mathrm{PL}=0.66 \mathrm{~mm} ; \mathrm{PW}=0.93 \mathrm{~mm}$;
$\mathrm{EL}=2.75 \mathrm{~mm} ; \mathrm{EW}=1.02 \mathrm{~mm}$. Length of the antennomeres, in $\mathrm{mm}:$ al $=0.25 ;$ all $=0.11$; all $=0.22 ;$ alV $=0.24$; $a V=0.24 ; a V I=0.22 ; a V I I=0.22 ; a V I I I=0.22 ; a I X=0.22$; $a X=0.21 ; a X I=0.22$. Paratype ơ: length $3.7 \mathrm{~mm}$.

Paratypes + : Differ from males in the smaller eyes, the shorter antennae, and the extension of the black patch of the pronotum, covering the apical half. Dimensions of one paratype $9 . \mathrm{TL}=3.7 \mathrm{~mm} ; \mathrm{AL}=2.5 \mathrm{~mm} ; \mathrm{HW}=0.7 \mathrm{~mm}$; $\mathrm{IOW}=0.42 \mathrm{~mm} ; \mathrm{OL}=0.18 \mathrm{~mm} ; \mathrm{IAW}=0.18 \mathrm{~mm}$; $\mathrm{PL}=0.68 \mathrm{~mm} ; \mathrm{PW}=0.96 \mathrm{~mm} ; \mathrm{EL}=2.8 \mathrm{~mm} ; \mathrm{EW}=0.98 \mathrm{~mm}$. Other paratype $\%$ : length $4.1 \mathrm{~mm}$.

Differential diagnosis: Plectonotum bicoloricolle sp. nov., is similar to the Ecuadorian species $P$. macar-

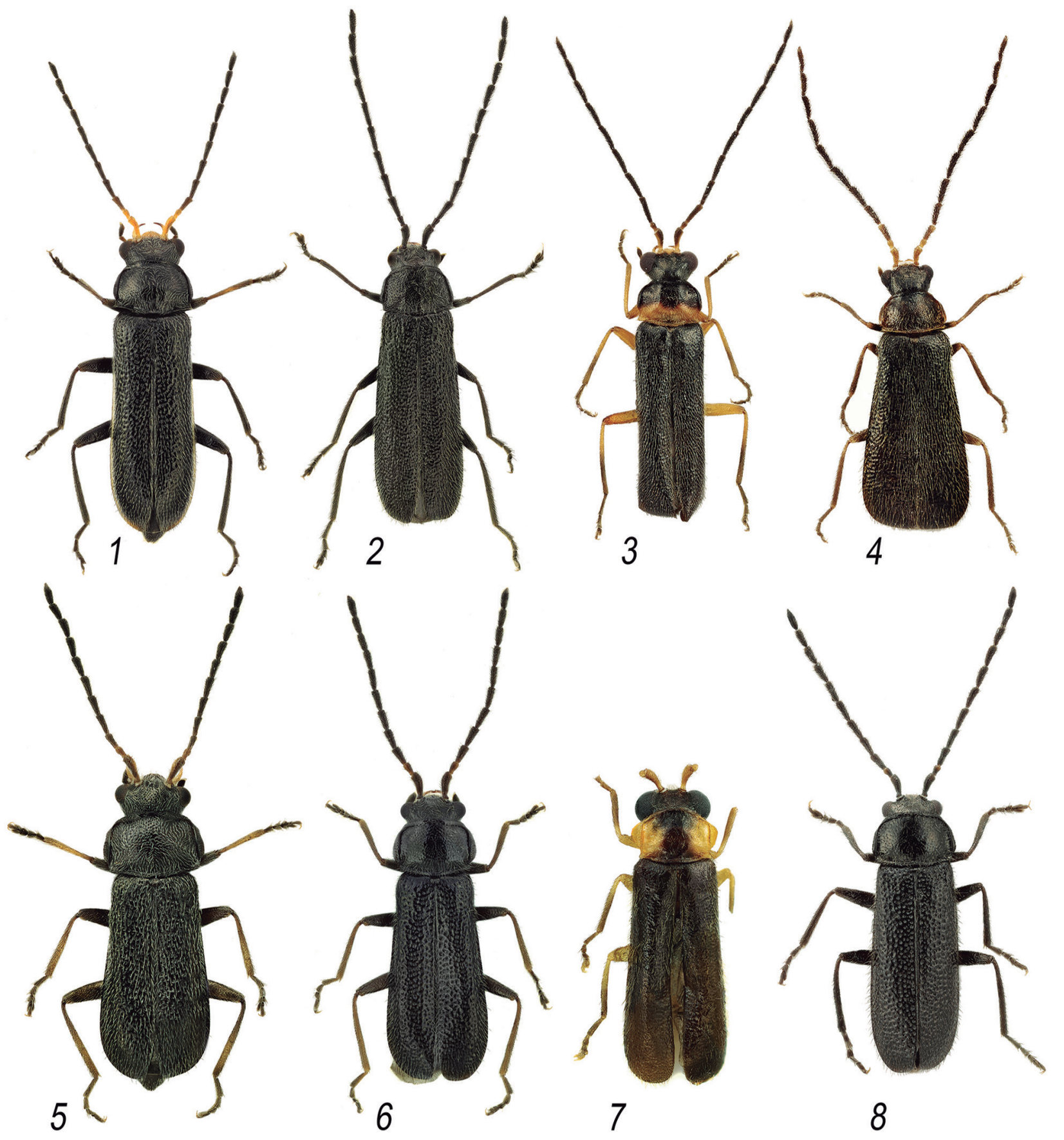

Figures 1-8. Plectonotum species, habitus dorsal. (1) Plectonotum altomayo sp. nov.; (2) P. amazonas sp. nov.; (3) P. bicoloricolle sp. nov.; (4) P. carpish sp. nov.; (5) P. celendin sp. nov.; (6) P. costae sp. nov.; (7) P. howdeni Wittmer; (8) P. huariaca sp. nov. 
aense Constantin, 2010, by the habitus, colour pattern and pronotal shape. It differs from the latter in the different aedeagus shape.

Etymology: Specific epithet recalls the peculiar pronotal colour.

Natural history: Collected beating shrubs and trees on the edge of a small wood.

\section{Plectonotum carpish sp. nov.} (Figs. 4, 27, 53-54, 96, 119)

Type material: Holotype $\sigma^{x}$ (MUSM): Peru, provincia de Huánuco, túnel de Carpish, lado norte, camino viejo, $09^{\circ} 43^{\prime} 12^{\prime \prime} \mathrm{S}, 76^{\circ} 05^{\prime} 56^{\prime \prime} \mathrm{W}, 2,705 \mathrm{~m}, 15 . \mathrm{IV} .2013$, leg. R. Constantin \& L. Huamán Cuespán. - Paratypes: 10", $2 q$, same locality and same date as holotype, leg. R. Constantin \& L. Huamán Cuespán; - 10', same locality, 01.IV.2015, leg. R. Constantin; - 10", same locality, 30.III.2017, leg. R. Constantin. Holotype and two paratypes deposited in MUSM, other paratypes preserved in author's collection (CCo).

Description: Holotype. Length $3.8 \mathrm{~mm}$. Head, pronotum and elytra brown, the lateral margins and the basal edge of pronotum brownish yellow. Antennae brown, the first two antenomeres yellow. Legs brownish yellow. Abdomen brown. Head 0.77 times as wide as pronotum, the clypeus short and rounded. Eyes short, strongly convex, bulging, the interocular space greater than half the width of the head. Frons slightly depressed behind the antennal sockets, flattened between the eyes. Temples strongly narrowing backwards. Cephalic surface smooth, without visible punctation and sparse adpressed thin yellowish setae. Antennae nearly as long as the body, the first two antennomeres smooth, the following parallel sided, slightly warty, covered with brown setae. Pronotum 1.64 times wider than long, transversally convex. Front edge right, rear edge feebly arched, lateral edge straight and narrowing frontwards with a narrow bead and a small emargination in front of the obtuse basal corners. Pronotal surface shiny, thinly punctate and shallowly wrinkled. Elytra 3.1 times longer than combined width at the base, markedly and irregularly punctate with transverse wrinkles, covered with dense, long (0.1-0.13 mm), recumbent yellow setae. Tarsi elongate, the metatarsus as long as the three-quarters of metatibia, the first tarsomere as long as the three following together. Sternite VIII long, apically rounded. Aedeagus: tegmen with lateral lobes reduced and notched posteriorly, the apico-ventral apophysis ventrally recurved; lateral sclerites and median lobe narrow.

Dimensions of the holotype: $T L=3.1 \mathrm{~mm} ; \mathrm{AL}=2.9 \mathrm{~mm}$; $\mathrm{HW}=0.59 \mathrm{~mm} ; \mathrm{IOW}=0.35 \mathrm{~mm} ; \mathrm{OL}=0.2 \mathrm{~mm}$; $I A W=0.15 \mathrm{~mm} ; \mathrm{PL}=0.47 \mathrm{~mm} ; \mathrm{PW}=0.77 \mathrm{~mm}$; $\mathrm{EL}=2.4 \mathrm{~mm} ; \mathrm{EW}=0.76 \mathrm{~mm}$. Length of the antennomeres, in $\mathrm{mm}$ : $a l=0.25 ;$ all $=0.11$; all $=0.22 ;$ alV $=0.24$; $a V=0.24 ; a V I=0.22 ; a V I I=0.22 ; a V I I I=0.22 ; a I X=0.22 ;$ $a X=0.21 ; a X I=0.22$. Paratypes $\sigma^{\text {r: }}$ length $2.7-3.2 \mathrm{~mm}$, mean: $3.0 \mathrm{~mm}$.

Paratypes $9:$ Differ from the males by the smaller eyes, the shorter antennae, the long subparallel temples, and the pronotum uniformly brown. Dimensions of one paratype . $\mathrm{TL}=3.0 \mathrm{~mm} ; \mathrm{AL}=1.56 \mathrm{~mm} ; \mathrm{HW}=0.51 \mathrm{~mm}$; $I O W=0.34 \mathrm{~mm} ; \mathrm{OL}=0.18 \mathrm{~mm} ; \mathrm{IAW}=0.17 \mathrm{~mm}$; $\mathrm{PL}=0.5 \mathrm{~mm} ; \mathrm{PW}=0.84 \mathrm{~mm} ; \mathrm{EL}=2.25 \mathrm{~mm} ; \mathrm{EW}=0.84 \mathrm{~mm}$. Other paratype $q$ : length $2.6 \mathrm{~mm}$.

Differential diagnosis: Plectonotum carpish sp. nov., is similar to the south Ecuadorian species $P$. incisum Constantin, 2008 by the habitus, colour pattern and pronotal shape. It differs from the latter in the smaller size, the pronotum narrowing frontward and the aedeagus shape.

Etymology: Specific epithet is related to the name of the Carpish pass, a remarkable hotspot of biodiversity between Huanuco and Tingo Maria. Noun in apposition.

Natural history: Collected beating the foliage of the trees, mainly large Asteraceae, along the ancient road.

\section{Plectonotum celendin sp. nov. (Figs. 5, 28, 55-56, 97, 119)}

Type material: Holotype ơ (MUSM): Peru, Cajamarca, provincia de Celendin, $17 \mathrm{~km} \mathrm{E}$ of Celendin, flowering shrubs, 06 50'42"S, 78 $06^{\prime} 53^{\prime \prime} \mathrm{W}$, alt. 2,915 m, 06.V.2018, leg. R. Constantin. Paratypes: 3 , same locality and date as the holotype. Holotype and one paratype deposited in the collection of the MUSM, other paratypes preserved in author's collection (CCO).

Description: Holotype ơ. Length $3.0 \mathrm{~mm}$. Head, prothorax, elytra and abdomen black. Antennae dark brown, the first two antennomeres reddish brown. Legs brown, the basal half of femora and the apical half of tibiae rufous. Head 0.75 times as wide as the pronotum, the clypeus protruding and medially notched. Eyes rather short, bulging, the interocular space 0.64 times as wide as the head. Frons flattened between the eyes. Temples short, narrowing backwards. Cephalic surface bright, thinly punctate, with yellowish setae. Antennae three quarters as long as the body, the first two antennomeres smooth, the following slightly triangular, dull, covered with short rufous setae. Pronotum 1.5 times wider than long, strongly convex, considerably wider at mid-length than both elytra. Front border arched, lined by a concave margin with a raised edge, rear edge feebly bi-sinuate, lateral edge convex with a long shiny bead and a short emargination in front of the obtuse basal corners. Pronotal surface shiny, strongly punctate, with punctations as wide as the intervals. Elytra 2.6 times longer than combined width at the base, strongly and irregularly punctate, covered with long, thin, recumbent pale-yellow setae. Aedeagus: teg- 
men with apico-ventral edge of the lateral lobes without median apophysis; apex of the lateral lobes short, triangular, the rear face with two brush-like groups of short setae; median lobe dorsally recurved, apically broad and notched; lateral sclerites broad, with rounded tips.

Dimensions of the holotype: $\mathrm{TL}=3.0 \mathrm{~mm} ; \mathrm{AL}=2.25 \mathrm{~mm}$; $\mathrm{HW}=0.75 \mathrm{~mm} ; \mathrm{IOW}=0.48 \mathrm{~mm} ; \mathrm{OL}=0.22 \mathrm{~mm}$; $I A W=0.19 \mathrm{~mm} ; \mathrm{PL}=0.66 \mathrm{~mm} ; \mathrm{PW}=1.0 \mathrm{~mm} ; \mathrm{EL}=2.1 \mathrm{~mm}$; $\mathrm{EW}=0.86 \mathrm{~mm}$. Length of the antennomeres, in $\mathrm{mm}$ : $a l=0.28 ;$ all $=0.12 ;$ all $=0.17 ;$ alV $=0.21 ; a V=0.21$ $a V I=0.21 \times 0.07 ; a V I I=0.21 ; a V I I I=0.20 ; a I X=0.19 ;$ $a X=0.17 ; a X I=0.22$.

Paratypes O: Differ from the male by the narrower head, the less convex eyes, and the shorter antennae. Dimensions of one paratype $9 . \mathrm{TL}=3.5 \mathrm{~mm} ; \mathrm{AL}=2.0 \mathrm{~mm}$; $\mathrm{HW}=0.74 \mathrm{~mm} ; \mathrm{IOW}=0.52 \mathrm{~mm} ; \mathrm{OL}=0.20 \mathrm{~mm}$; $I A W=0.23 \mathrm{~mm} ; \mathrm{PL}=0.73 \mathrm{~mm} ; \mathrm{PW}=1.1 \mathrm{~mm} ; E L=2.55 \mathrm{~mm}$; $E W=1.05 \mathrm{~mm}$. Other paratypes 9 : length 3.2 and $3.7 \mathrm{~mm}$.

Differential diagnosis: Plectonotum celendin sp. nov., is similar to $P$. altomayo sp. nov., by the pronotal bead and elytral punctation. It differs from the latter in the smaller size, the wider pronotum, the irregularly aligned elytral punctations and the aedeagus with lateral lobes apically pubescent.

Etymology: Specific epithet is related to the provincial name of a remarkable station between Celendin and Leymebamba. Noun in apposition.

Natural history: Collected beating the foliage of flowering bushes, mainly Asteraceae, in the morning.

\section{Plectonotum costae sp. nov. (Figs. 6, 29, 57-58, 98, 119)}

Type material: Holotype $\sigma^{x}$ (MUSM): Peru, Cajamarca, provincia de Celendin, Punre $500 \mathrm{~m} \mathrm{~S}$, flowering shrubs, 06 59'53"S, 78 $17^{\prime} 07^{\prime \prime} \mathrm{W}$, alt. 3,460 m, 05.V.2018, leg. R. Constantin. Paratypes: $50^{\circ}, 29$, same locality and date as the holotype, leg. R. Constantin. Holotype and three paratypes deposited in the collection of the MUSM, other paratypes preserved in author's collection (CCo).

Description: Holotype. Length $3.7 \mathrm{~mm}$. Head, pronotum and elytra black. Antennae black, the ventral face of the second antennomere orange-yellow. Legs black, the apical half of tibiae and tarsi brown. Abdomen brown Head 0.77 times as wide as pronotum, the clypeus feebly arched. Eyes short, bulging, the interocular space 0.66 times as wide as the head. Frons feebly convex between the eyes. Temples short and convex. Cephalic surface smooth, markedly punctate, with thin whitish setae. Antennae shorter than the body, the first antennomere smooth, the following parallel sided, slightly dull, covered with thin fulvous setae. Pronotum 1.5 times wider than long, longitudinally and transversally convex. Front edge feebly arched; front corners bevelled; lateral edge rounded with a convex bead, wider at mid-length and narrowing frontwards and backwards and a notch in front of the basal corners; basal edge feebly bi-sinuous, strongly punctate. Pronotal surface shiny, strongly punctate on the disc, more thinly near the sides with punctations 0.66 times as wide as intervals. Elytra 2.55 times longer than combined width at the base, markedly punctate, the punctations irregularly seriate, covered with long, thin, recumbent whitish setae. Aedeagus: tegmen with apico-ventral edges reduced and extended dorsally by a long, slender apophysis; lateral sclerites with a long tooth at mid-length, their tips folded ventrally; median lobe with thin tip.

Dimensions of the holotype: $\mathrm{TL}=3.7 \mathrm{~mm} ; \mathrm{AL}=2.85 \mathrm{~mm}$; $\mathrm{HW}=0.85 \mathrm{~mm} ; \mathrm{IOW}=0.58 \mathrm{~mm} ; \mathrm{OL}=0.25 \mathrm{~mm} ;$ IAW $=0.21 \mathrm{~mm} ; \mathrm{PL}=0.75 \mathrm{~mm} ; \mathrm{PW}=1.12 \mathrm{~mm}$; $\mathrm{EL}=2.6 \mathrm{~mm} ; \mathrm{EW}=1.02 \mathrm{~mm}$. Length of the antennomeres, in $\mathrm{mm}$ : $a l=0.30 ;$ all $=0.17$; all $=0.25$; $a \mathrm{IV}=0.28$; $a V=0.29 ; a V I=0.27 ; a V I I=0.25 ; a V I I I=0.25 ; a I X=0.25$; $a X=0.24 ; a X I=0.26$. Paratypes $\sigma^{x}$ : length 3.3-3.5 mm.

Paratypes $9:$ Differ from the males by smaller and less bulging eyes, the shorter antennae, and the more transverse pronotum. Dimensions of one paratype $q$. $\mathrm{TL}=3.7 \mathrm{~mm} ; \mathrm{AL}=1.9 \mathrm{~mm} ; \mathrm{HW}=0.8 \mathrm{~mm} ; \mathrm{IOW}=0.58 \mathrm{~mm}$; $\mathrm{OL}=0.21 \mathrm{~mm} ; \mathrm{IAW}=0.24 \mathrm{~mm} ; \mathrm{PL}=0.77 \mathrm{~mm}$; $\mathrm{PW}=1.18 \mathrm{~mm} ; \mathrm{EL}=2.7 \mathrm{~mm} ; \mathrm{EW}=1.1 \mathrm{~mm}$. Other paratypes o: length $3.8-3.9 \mathrm{~mm}$.

Differential diagnosis: Plectonotum costae sp. nov., is similar to P. amazonas sp. nov., by the size and body colour, but differs in the lateral bead, convex and dilated in its centre, the shorter antennae and the aedeagus with the latero-apical parts of tegmen projecting dorsally, and a slender and acute apophysis.

Etymology: Respectfully dedicated to honor Doutora Cleide Costa, prominent specialist of the immatures and adults of the Coleoptera Elateroidea, and also for her major investment in the training of a new generation of entomologists.

Natural history: Collected beating the foliage of wet trees, after a short midday rain, on the hedge of the earth road, $500 \mathrm{~m}$ before reaching Punre village, together with the cantharids Plectonotum huertoae sp. nov., Chauliognathus cf. nigronotaticeps Pic, 1947 and Discodon humeropictum Wittmer, 1954.

\section{Plectonotum huariaca sp. nov. (Figs. 8, 31, 61-62, 100, 119)}

Type material: Holotype $\sigma^{\pi}$ (MUSM): Peru, provincia de Pasco, $30 \mathrm{~km} \mathrm{~N}$ de Cerro de Pasco, Huariaca $5 \mathrm{~km} \mathrm{~S}$, $10^{\circ} 30^{\prime} 07^{\prime \prime} \mathrm{S}, 76^{\circ} 10^{\prime} 50^{\prime \prime} \mathrm{W}$, alt. 3,290 m, 31.III.2017, leg. R. Constantin. Paratypes: $10^{\circ}, 8 \%$, same locality and date as the holotype; - 10", 39, provincia de Huanuco, $30 \mathrm{~km} \mathrm{~W}$ de 


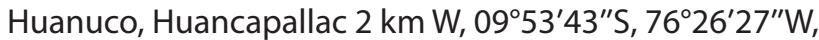
alt. 3,055 m, 01.IV.2017, leg. R. Constantin. Holotype and six paratypes deposited in the collection of MUSM, other paratypes preserved in the author's collection (CCO).

Description: Holotype. Length $2.9 \mathrm{~mm}$. Head black, clypeus rufous. Mandibles yellow with brown tip. Palpi brown. Antennomeres I-II fulvous, III-XI black. Pronotum, elytra and abdomen black. Legs brown. Head 0.76 times as wide pronotum. Eyes small, feebly bulging. Frons flattened between the eyes, the vertex slightly convex. Temples long, convex. Cephalic surface glossy, without visible punctation, covered with long, thin yellowish setae, directed toward the base of the eyes. Antennae slender, the first antennomere elongate, feebly arched, three times longer than wide, II short, III slightly wider apically and twice longer than wide, the following subparallel-sided. Pronotum 1.62 times wider than long. Front edge right, rear edge weakly arched, both thinly bordered, lateral edges right in the middle part with a nar-

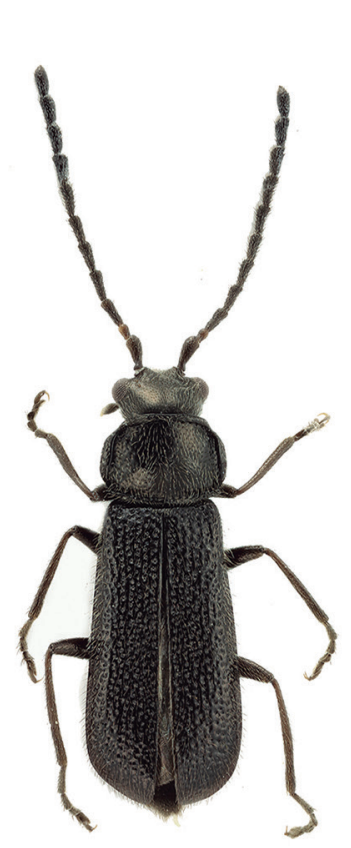

9

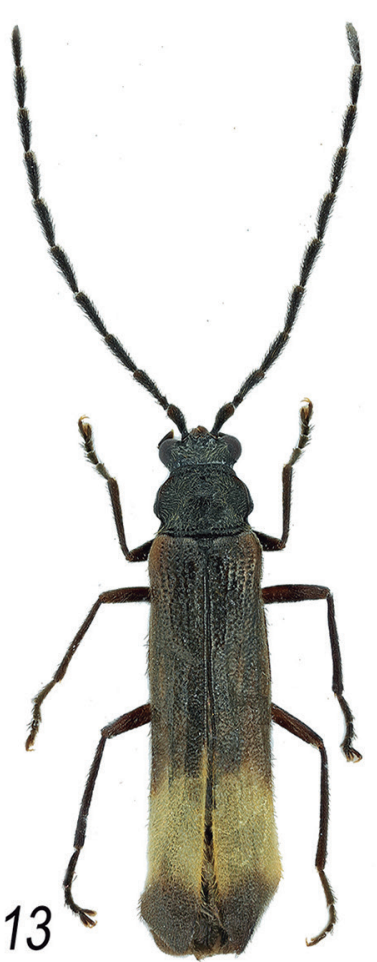

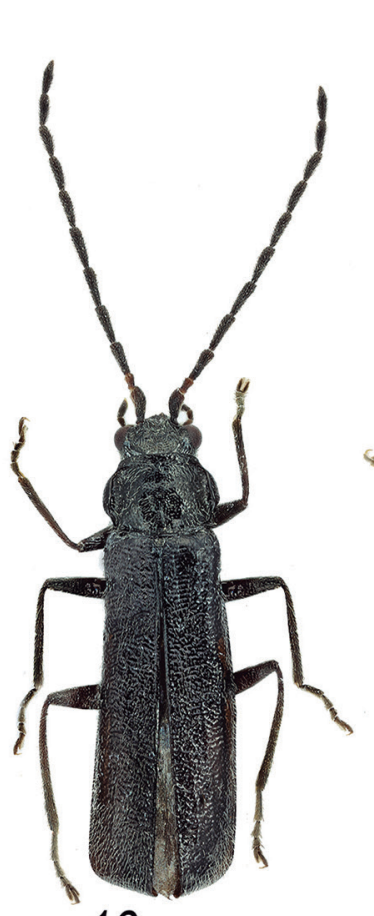

10

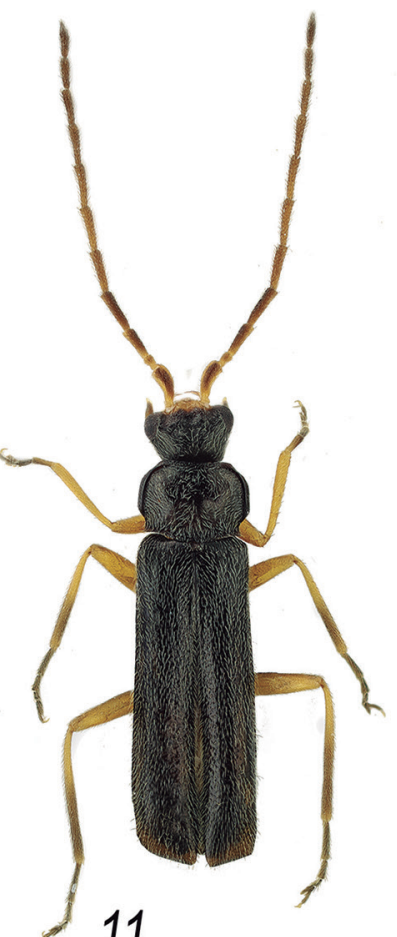

11
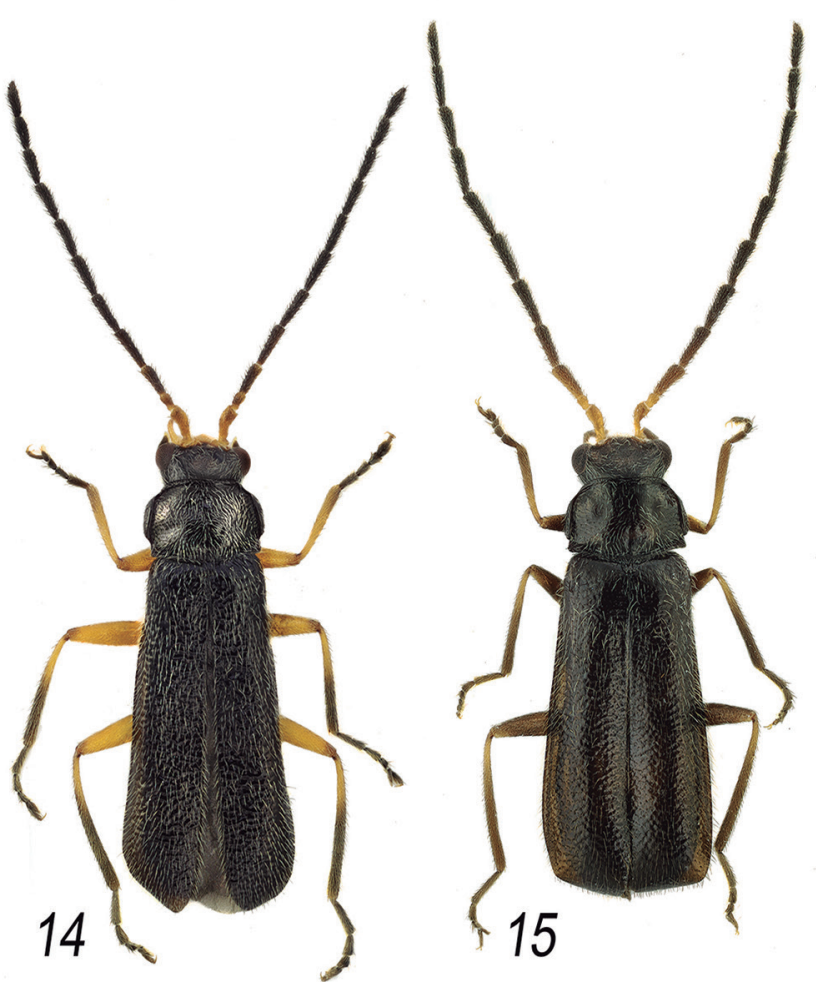

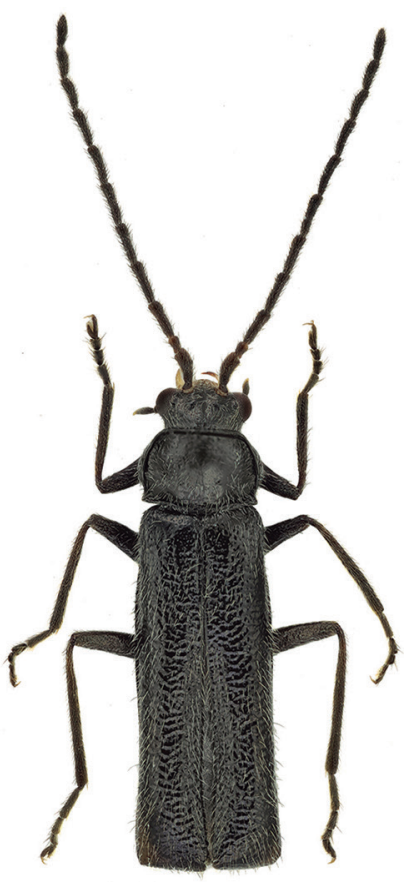

12

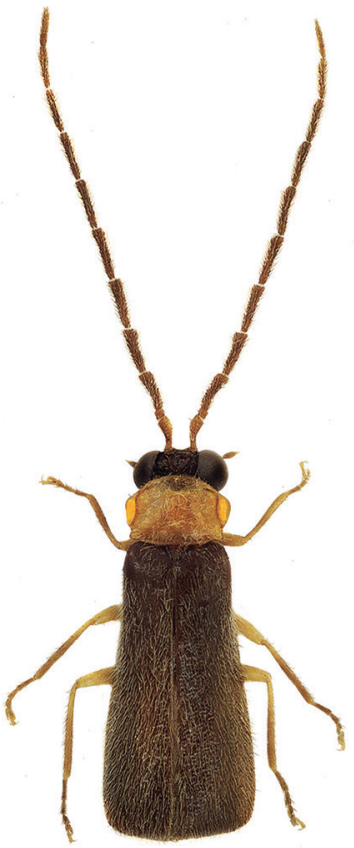

16

Figures 9-16. Plectonotum species habitus dorsal. (9) Plectonotum huascaran sp. nov.; (10) P. huertoae sp. nov.; (11) P. inca Wittmer; (12) P. leymebamba sp. nov.; (13) P. Iongissimum (Pic); (14) P. luteipes sp. nov.; (15) P. martinezi Wittmer; (16) P. neoruficolle nom. nov. 
row bead, apical corner obliquely bevelled, basal corner right angled. Disc convex, glossy with thin punctation and long adpressed yellowish setae. Elytra 2.6 times longer than their combined width at the base, not costate, the apex widely rounded. Elytral surface weakly subseriate and roughly punctate, the punctations 1.5 times wider than their intervals, covered with long yellowish setae, obliquely directed backwards. Legs simples, tarsi rather elongate, the metatarsi about three-fifths of metatibial length, the claws thin, without basal denticles. Abdominal sternite VIII subquadrate with rounded apical corners. Aedeagus: tegmen as long as wide; apices of lateral lobes subquadrate; apico-ventral apophysis long, narrow. Lateral sclerites narrow, denticulate in their centre. Median lobe short, with narrow recurved tip.

Dimensions of the holotype: $\mathrm{TL}=2.9 \mathrm{~mm} ; \mathrm{AL}=2.15 \mathrm{~mm}$; $\mathrm{HW}=0.64 \mathrm{~mm} ; \mathrm{IOW}=0.41 \mathrm{~mm} ; \mathrm{OL}=0.19 \mathrm{~mm}$; $\mathrm{IAW}=0.14 \mathrm{~mm} ; \mathrm{PL}=0.52 \mathrm{~mm} ; \mathrm{PW}=0.84 \mathrm{~mm}$; $\mathrm{EL}=2.12 \mathrm{~mm} ; \mathrm{EW}=0.82 \mathrm{~mm}$. Length of the antennomeres, in $\mathrm{mm}$ : $a \mathrm{l}=0.26$; all $=0.1$; all $=0.19$; $a \mathrm{IV}=0.24$; $a V=0.27 ; a V I=0.27 ; a V I I=0.28 ; a V I I I=0.26 ; a I X=0.25$; $a X=0.23 ; a X I=0.26$. Paratypes $\sigma^{x}$ : length $2.4-3.1 \mathrm{~mm}$, mean $2.7 \mathrm{~mm}$.

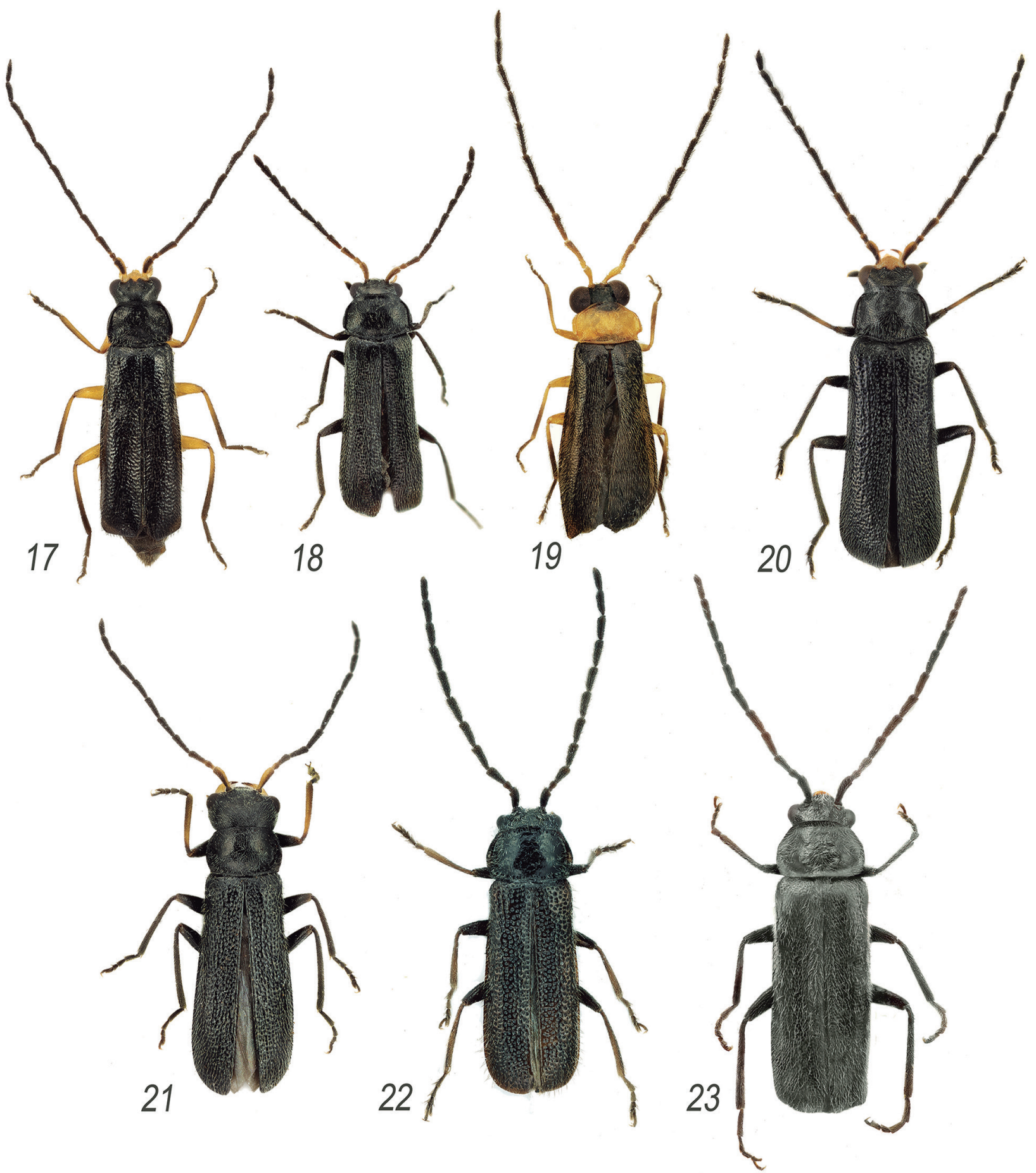

Figures 17-23. Plectonotum and Hyponotum species, habitus dorsal. (17) Plectonotum oxapampa sp. nov.; (18) P. peruanum Wittmer. (19) P. rubrithorax sp. nov.; (20) P. shipasbamba sp. nov.; (21) Hyponotum macrocephalum sp. nov.; (22) H. succhabamba sp. nov.; (23) H. philippii (Gemminger). 
Paratypes $9:$ Differ from the males by the smaller eyes, shorter antennae, pronotal width broader than elytral base, complete lack of metathoracic wing, weakly-marked humeral calli, and shorter elytra covered with shorter pubescence. Dimensions of a medium sized specimen \%. $\mathrm{TL}=2.7 \mathrm{~mm} ; \mathrm{AL}=1.9 \mathrm{~mm} ; \mathrm{HW}=0.61 \mathrm{~mm}$; $I O W=0.45 \mathrm{~mm} ; \mathrm{OL}=0.17 \mathrm{~mm} ; \mathrm{IAW}=0.16 \mathrm{~mm}$; $\mathrm{PL}=0.54 \mathrm{~mm} ; \mathrm{PW}=0.9 \mathrm{~mm} ; \mathrm{EL}=2.0 \mathrm{~mm} ; \mathrm{EW}=0.84 \mathrm{~mm}$. Paratypes o: length $2.5-3.1 \mathrm{~mm}$, mean $2.8 \mathrm{~mm}$.
Differential diagnosis: Plectonotum huariaca sp. nov., is similar to the Ecuadorian species P. nigricorne Constantin, 2008 by the habitus, colour pattern and pronotal shape. It differs from the latter in the shape of the aedeagus and the peculiar apterism of the females.

Etymology: The specific epithet is the locality name, which could mean "locality with warm air", or as a homage to the General Inca Inti-Waraca. Noun in apposition.

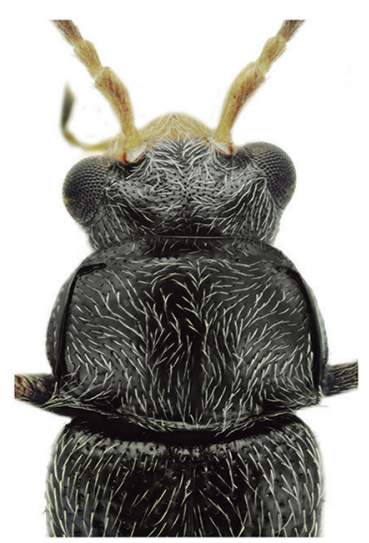

24

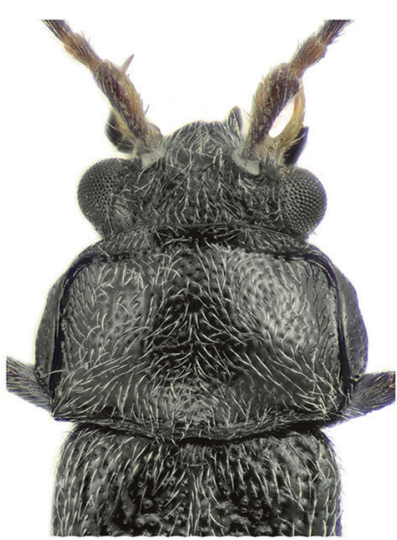

28

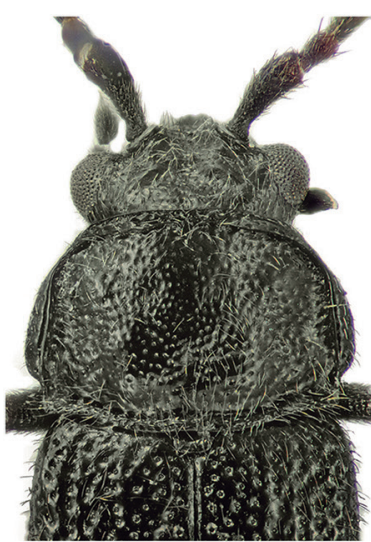

32

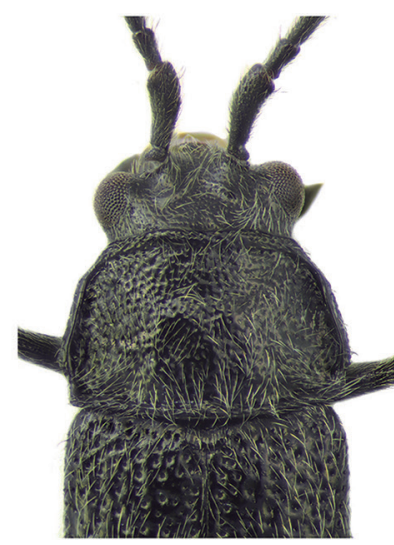

25

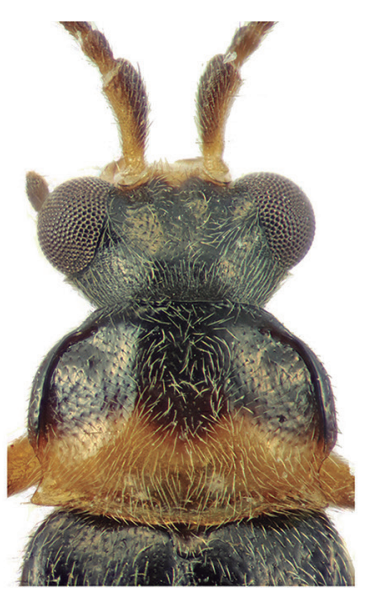

26

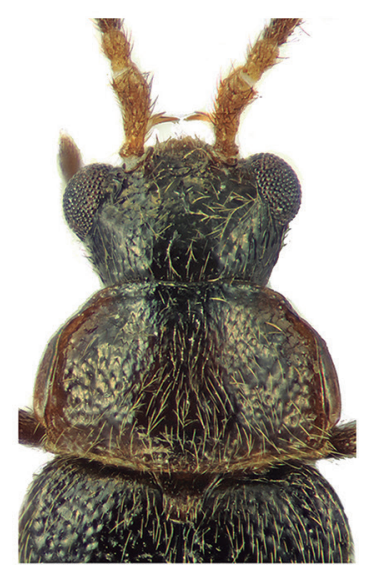

27

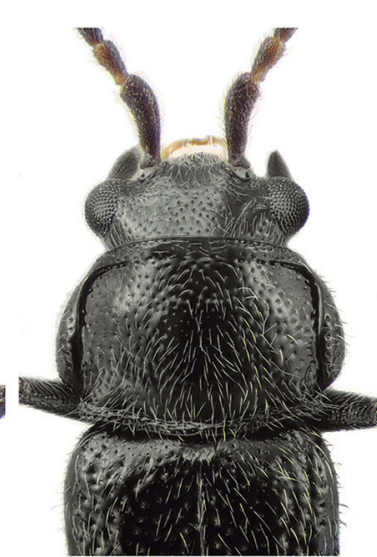

29

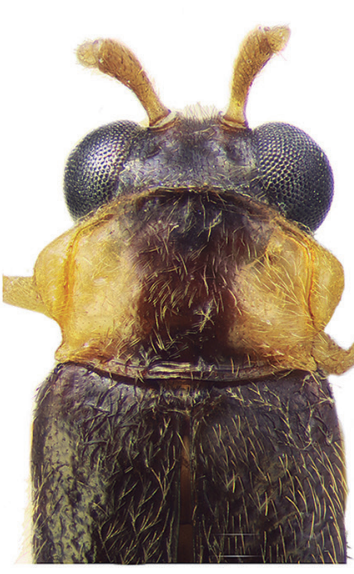

30

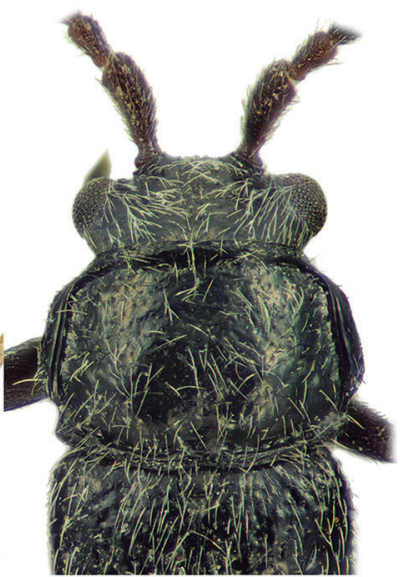

31

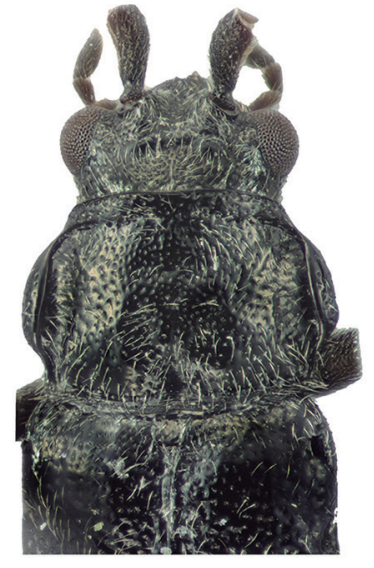

33

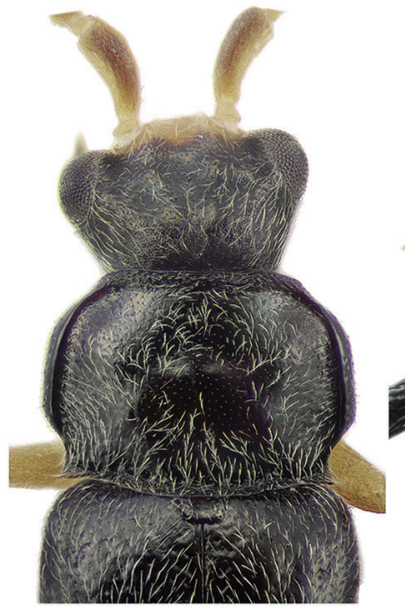

34

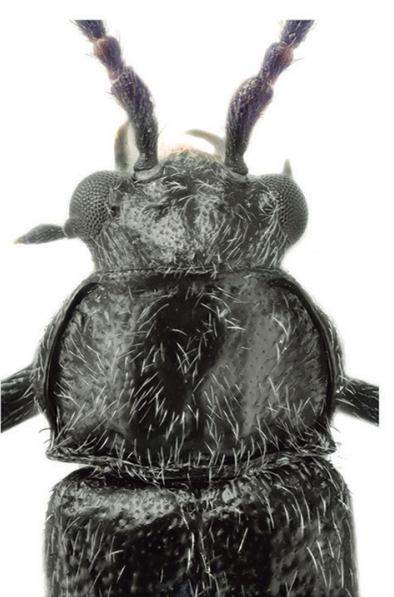

35

Figures 24-35. Plectonotum species, head and pronotum. (24) Plectonotum altomayo sp. nov.; (25) P. amazonas sp. nov.; (26) P. bicoloricolle sp. nov.; (27) P. carpish sp. nov.; (28) P. celendin sp. nov.; (29) P. costae sp. nov.; (30) P. howdeni Wittmer; (31) P. huariaca sp. nov.; (32) P. huascaran sp. nov.; (33) P. huertoae sp. nov.; (34) P. inca Wittmer; (35) P. leymebamba sp. nov. 
Natural history: Collected beating low Asteraceae bushes among pastured meadows.

\section{Plectonotum huascaran sp. nov. (Figs. 9, 32, 63-64, 101, 119)}

Type material: Holotype on (MUSM): Peru, Ancash, provincia de Yungay, $15 \mathrm{~km}$ NE de Yungay, carret-

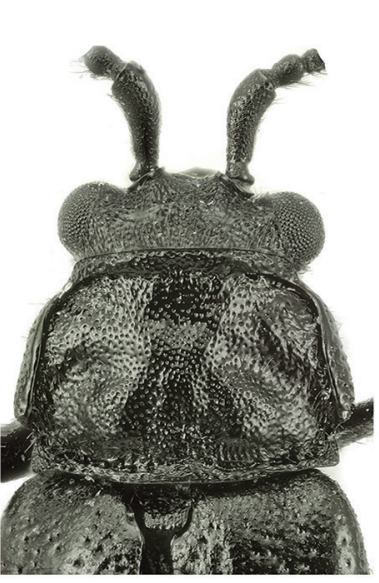

36

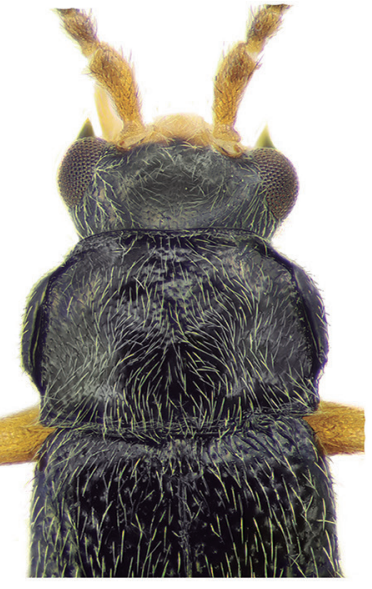

37

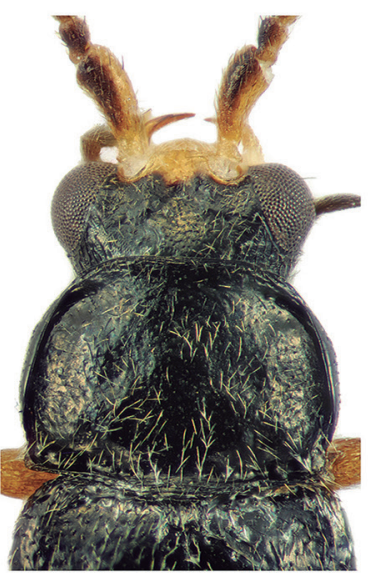

40

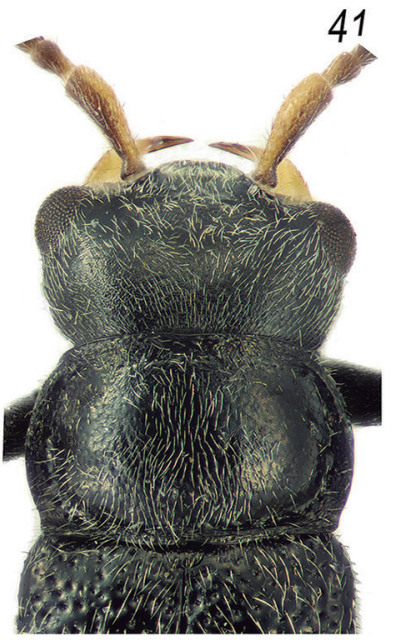

44

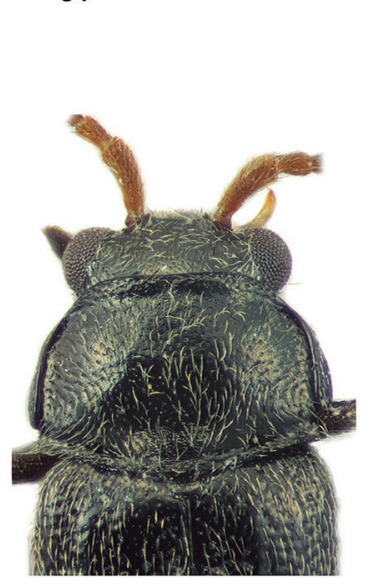

41

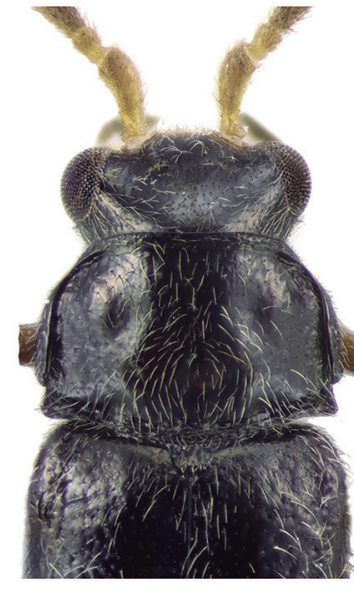

38

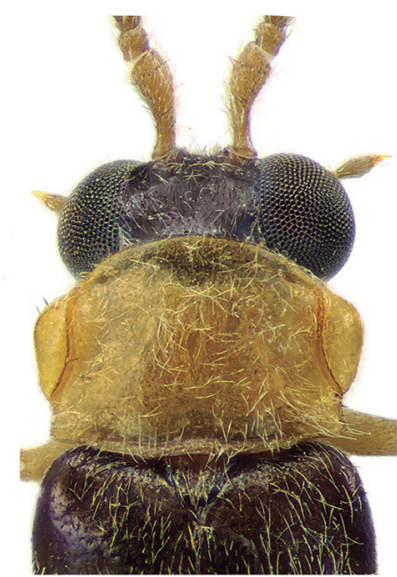

39 era de Laguna Llanganuco, $09^{\circ} 06^{\prime} 03^{\prime \prime} \mathrm{S}, 77^{\circ} 40^{\prime} 20^{\prime \prime} \mathrm{W}$, alt. 3,465 m, 03.IV.2017, leg. R. Constantin. Paratypes: $20^{\prime \prime}, 3$, same date and locality as the holotype; - 4o', 4\%, Ancash, provincia de Huaylas, 20 km E de Caraz,

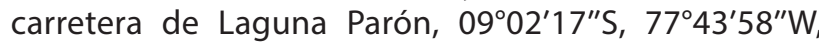
alt. 3,370 m, 08.IV.2015, leg. R. Constantin. Holotype and six paratypes deposited in the collection of MUSM, other paratypes preserved in the author's collection (CCo).

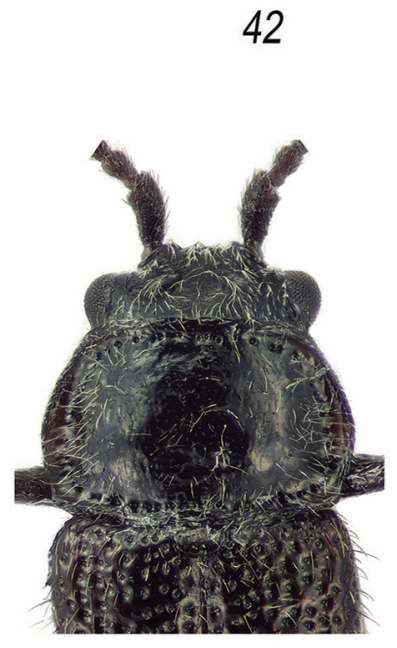

45

42
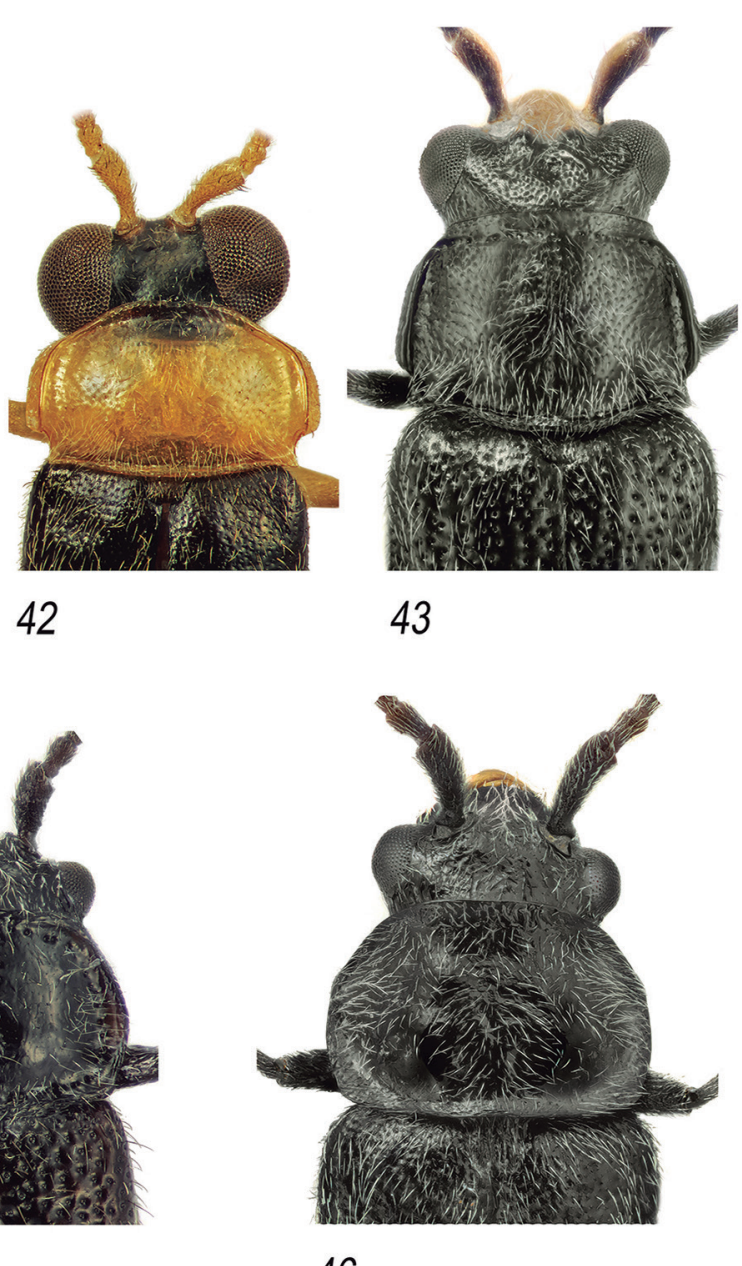

Figures 36-46. Plectonotum and Hyponotum, head and pronotum. (36) Plectonotum longissimum (Pic); (37) P. luteipes sp. nov.; (38) P. martinezi Wittmer; (39) P. neoruficolle nom. nov.; (40) P. oxapampa sp. nov.; (41) P. peruanum Wittmer. (42) P. rubrithorax sp. nov.; (43) P. shipasbamba sp. nov.; (44) Hyponotum macrocephalum sp. nov.; (45) H. succhabamba sp. nov.; (46) H. philippii (Gemminger). 
Description: Holotype. Length $3.2 \mathrm{~mm}$. Head, pronotum and elytra black. Antennae black, the ventral face of the first two antennomeres brownish yellow. Mandibles yellow with brown tip. Abdomen brown. Head 0.76 times as wide as pronotum. Eyes small, bulging. Frons concave between the antennal sockets, flat behind, the vertex slightly convex. Temples as long as the eyes, slightly convex. Cephalic surface smooth, thinly punctate, covered with thin yellowish setae, directed toward the base of the eyes. Antennae slender, the first antennomere elongate, two and a quarter times longer than wide, II short, III slightly wider apically and two and a half times longer than wide, the following subparallel sided. Pronotum 1.37 times wider than long. Apical and basal edges weakly arched, both thinly bordered, lateral edges straight in the middle part with a narrow bead, apical corner obliquely bevelled, basal corner shortly right angled. Disc convex, bright, markedly punctate, covered with recumbent yellowish setae. Elytra 2.6 times longer than their combined width at the base and 0.9 times as wide as pronotum, not costate, roughly punctated, the punctation twice wider than their intervals, seriately disposed on the basal half, more irregularly apically, covered with thin whitish setae, obliquely directed backwards. Elytral apices rounded continuously together with the lateral margin. Legs simple, tarsi rather elongate, the metatarsi as long as the two thirds of metatibiae, the claws thin, without basal denticles. Abdominal sternite VIII wide and triangular, the apical edge arched and truncate. Aedeagus: tegmen 2.6 times longer than wide, apices of lateral lobes broadly rounded, apico-ventral apophysis thin, narrow; lateral sclerites triangular-shaped, narrow; median lobe short, with recurved tip.

Dimensions of the holotype: $\mathrm{TL}=3.2 \mathrm{~mm} ; \mathrm{AL}=2.2 \mathrm{~mm}$; $\mathrm{HW}=0.71 \mathrm{~mm} ; \mathrm{IOW}=0.45 \mathrm{~mm} ; \mathrm{OL}=0.21 \mathrm{~mm}$; $\mathrm{IAW}=0.2 \mathrm{~mm} ; \mathrm{PL}=0.67 \mathrm{~mm} ; \mathrm{PW}=0.92 \mathrm{~mm} ; \mathrm{EL}=2.2 \mathrm{~mm}$; $\mathrm{EW}=0.84 \mathrm{~mm}$. Length of the antennomeres, in $\mathrm{mm}$ : $a l=0.25 ;$ all $=0.11 ;$ all $=0.22 ; a I V=0.24 ; a V=0.24$; $a V I=0.22 ; a V I I=0.22 ; a V I I I=0.22 ; a I X=0.22 ; a X=0.21$; $a X I=0.22$. Paratypes o': length $3.0-3.8 \mathrm{~mm}$, mean $3.4 \mathrm{~mm}$.

Paratypes o: Differ from the males by the smaller eyes, shorter antennae, pronotum more strongly narrowed towards the apex, and elytra 1.36 times broader apically than basally. Sternite VIII short and wide, the apical edge deeply incised in the middle. Dimensions of a medium sized specimen \%. $\mathrm{TL}=3.5 \mathrm{~mm} ; \mathrm{AL}=2.2 \mathrm{~mm} ; \mathrm{HW}=0.7 \mathrm{~mm}$; $\mathrm{IOW}=0.49 \mathrm{~mm} ; \mathrm{OL}=0.18 \mathrm{~mm} ; \mathrm{IAW}=0.21 \mathrm{~mm}$; $\mathrm{PL}=0.68 \mathrm{~mm} ; \mathrm{PW}=1.08 \mathrm{~mm} ; \mathrm{EL}=2.6 \mathrm{~mm} ; \mathrm{EW}=0.98 \mathrm{~mm}$. Paratypes o: length $3.1-4.1 \mathrm{~mm}$, mean $3.5 \mathrm{~mm}$.

Differential diagnosis: Plectonotum huascaran sp. nov., resembles to the Ecuadorian species $P$. nigricorne Constantin, 2008, and P. huariaca sp. nov., by the habitus, colour pattern and pronotal shape. It differs from the latter by the bigger size, the more seriate elytral punctation, the the characters of the aedeagus, and the females with fully developed wings.
Etymology: Specific epithet is related to the name of the National Park Huascaran on the Cordillera Blanca. Noun in apposition.

Natural history: Collected beating the foliage of the trees along the access road to the mountains lakes.

\section{Plectonotum huertoae sp. nov. (Figs. 10, 33, 65-66, 102, 119)}

Type material: Holotype ơ (MUSM): Peru, Cajamarca, provincia de Celendin, Sorochuco, El Punre, $06^{\circ} 59^{\prime} 28^{\prime \prime} \mathrm{S}$, 78 17'17", alt. 3,652 m, 11-12.IV.2009, leg. L. Huerto. Paratypes: $10^{x}, 19$, same locality and date as the holotype, leg. L. Huerto (MUSM); - 19 ex., provincia de Celendin, Punre, initio de la carretera de la Mina Galeno, flowering shrubs, $06^{\circ} 59^{\prime} 51^{\prime \prime} \mathrm{S}, 78^{\circ} 17^{\prime} 25^{\prime \prime} \mathrm{W}$, alt. 3,636 m, 05.V.2018, leg. R. Constantin; - 120', 4ㅇ, provincia de Celendin, Punre $500 \mathrm{~m} \mathrm{~S}$, flowering shrubs, 0659'53"S, 78 ${ }^{\circ} 17^{\prime} 07^{\prime \prime} W$, alt. 3,460 m, 05.V.2018, leg. R. Constantin. Holotype and fifteen paratypes deposited in the collection of the MUSM, other paratypes preserved in author's collection (CCo).

Description: Holotype. Length $5.0 \mathrm{~mm}$. Head, pronotum, elytra and abdomen black. Antennae black, the second antennomere rufous brown. Mandibles yellow. Legs brown. Head 0.76 times as wide as pronotum. Eyes small, very convex, bulging, the inter-ocular space twice as wide as the length of eye. Clypeus protruding. Frons concave between the antennal sockets, flat behind. Temples short and right. Cephalic surface shiny, strongly punctate, the punctation one and a half as wide as the intervals, with sparse yellowish setae. Pronotum 1.42 times wider than long, thinly bordered all around, the lateral sides with a convex, narrow bead, the apical corners shortly bevelled and concave, the basal corners obtuse angled, not protruding. Pronotal surface irregular, shiny, strongly punctate on the disc and smaller punctations on the sides. Elytra distinctly elongate, 3.4 times longer than wide basally, with trace of a single narrow costa, strongly and irregularly punctate, the punctations shallowly wrinkled, as wide as three times their intervals. Sternite VIII densely micropunctate, elongate and apically rounded. Aedeagus: tegmen with apices of lateral lobes strongly emarginated, apical angles laterally as long as wide; lateral sclerites apically wide with a preapical denticle.

Dimensions of the holotype: $T L=5.0 \mathrm{~mm} ; A L=3.9 \mathrm{~mm}$; $\mathrm{HW}=0.86 \mathrm{~mm} ; \mathrm{IOW}=0.52 \mathrm{~mm} ; \mathrm{OL}=0.27 \mathrm{~mm}$; $\mathrm{IAW}=0.22 \mathrm{~mm} ; \mathrm{PL}=0.8 \mathrm{~mm} ; \mathrm{PW}=1.14 \mathrm{~mm} ; \mathrm{EL}=3.9 \mathrm{~mm}$; $\mathrm{EW}=1.14 \mathrm{~mm}$. Length of the antennomeres, in $\mathrm{mm}$ : $a l=0.35 ;$ all $=0.14 ;$ all $=0.33 ; a I V=0.38 ; a V=0.39$; $a V I=0.4 ; a V I I=0.38 ; a V I I I=0.37 ; a I X=0.32 ; a X=0.31$;

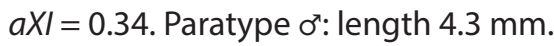

Paratypes o: Differ from the males by the smaller eyes and shorter antennae. Sternite VIII densely micropunctate, short and wide, the apical edge deeply incised in 
the middle. Dimensions $9 . \mathrm{TL}=4.4 \mathrm{~mm} ; \mathrm{AL}=2.7 \mathrm{~mm}$; $\mathrm{HW}=0.73 \mathrm{~mm} ; \mathrm{IOW}=0.5 \mathrm{~mm} ; \mathrm{OL}=0.21 \mathrm{~mm}$; $I A W=0.21 \mathrm{~mm} ; \mathrm{PL}=0.66 \mathrm{~mm} ; \mathrm{PW}=1.07 \mathrm{~mm} ; \mathrm{EL}=3.3 \mathrm{~mm}$; $\mathrm{EW}=1.06 \mathrm{~mm}$

Differential diagnosis: Plectonotum huertoae sp. nov., is similar to the Peruvian species P. longissimum (Pic, 1927) by the elongate elytra, and differs of the latter by the smaller size, shiny surface, stronger and less dense pronotal punctation, and different aedeagus shape.

Etymology: Respectfully dedicated to Luz Maria Huerto Santillá, biologist and entomologist at the MUSM, specialist of Diptera, Tephritidae. L. M. Huerto was the collector of the first three type specimens in this interesting site during inventories field works.

\section{Plectonotum leymebamba sp. nov. (Figs. 12, 35, 69-70, 104, 119)}

Type material: Holotype $\sigma^{\prime \prime}$ (MUSM): Peru, Amazonas, provincia de Chachapoyas, Leymebamba $2 \mathrm{~km}$ SW, flowering shrubs, $06^{\circ} 42^{\prime} 53^{\prime \prime} \mathrm{S}, 77^{\circ} 49^{\prime} 06^{\prime \prime} \mathrm{W}$, alt. 2,700 m, 08.V.2018, leg. R. Constantin. Paratypes: $30^{\circ}, 2 \%$, same locality and date as the holotype, leg. R. Constantin. Holotype and two paratypes deposited in the collection of the MUSM, other paratypes preserved in author's collection (CCo).

Description: Holotype. Length $4.0 \mathrm{~mm}$. Head black, the clypeus and the genae orange yellow in front of the antennal sockets. Antennae black, the first two antennomeres with orange yellow ventral side. Mandibles yellow. Labial and maxillary palpi black, their first joint yellow. Prothorax, elytra, abdomen and legs black. Head 0.76 times as wide as pronotum, the clypeus triangularly protruding. Eyes developed, bulging, the interocular space 0.6 times as wide as the head. Frons broad, flattened between the eyes with a median longitudinal depression and two small oblique bumps behind the antennal sockets. Temples short, narrowing backwards. Cephalic surface smooth, very thinly punctate, with thin whitish setae. Antennae 0.8 times as long as the body, the first two antennomeres smooth, the following parallel sided, dull, covered with erected brownish setae. Pronotum 1.47 times wider than long, feebly transversally convex. Front edge slightly arched, rear edge angular, lateral edge moderately narrowing frontwards, rounded with a long narrow bead and a short emargination in front of the basal corners. Pronotal surface shiny, thinly punctate, the punctations twice smaller than the intervals. Elytra 2.8 times longer than combined width at the base, the punctations shallow, rugulose and irregularly disposed, covered with long, thin, obliquely erected pale yellow setae. Aedeagus: tegmen with apex of the lateral lobes parallel sided in dorsal view, forming a rectangular lamina with dense and very long apical setae in lateral view; apico-ventral apophysis slender, their tips with a minute hook; lateral sclerites narrow, straight, the tooth at mid-length minute; median lobe with a narrow styliform projection.

Dimensions of the holotype: $T L=4.0 \mathrm{~mm} ; \mathrm{AL}=3.25 \mathrm{~mm}$; $\mathrm{HW}=0.83 \mathrm{~mm} ; \mathrm{IOW}=0.50 \mathrm{~mm} ; \mathrm{OL}=0.29 \mathrm{~mm}$; $\mathrm{IAW}=0.19 \mathrm{~mm} ; \mathrm{PL}=0.74 \mathrm{~mm} ; \mathrm{PW}=1.09 \mathrm{~mm}$; $\mathrm{EL}=3.0 \mathrm{~mm} ; \mathrm{EW}=1.06 \mathrm{~mm}$. Length of the antennomeres, in $\mathrm{mm}: a l=0.32 ;$ all $=0.13$; all $=0.31$; $a \mathrm{IV}=0.35$; $a V=0.35 ; a V I=0.35 \times 0.09 ; a V I I=0.32 ; a V I I I=0.32 ;$ $a I X=0.27 ; a X=0.25 ; a X I=0.28$. Paratypes or: length 3.9-4.1 mm.

Paratypes \%: Differs from the males by the less convex eyes, shorter antennae and pronotum narrower anteriorly. Dimensions of one paratype $\%$. $T L=4.2 \mathrm{~mm}$; $\mathrm{AL}=2.6 \mathrm{~mm} ; \mathrm{HW}=0.75 \mathrm{~mm} ; \mathrm{IOW}=0.50 \mathrm{~mm} ;$ $\mathrm{OL}=0.24 \mathrm{~mm} ; \mathrm{IAW}=0.21 \mathrm{~mm} ; \mathrm{PL}=0.72 \mathrm{~mm} ;$ $\mathrm{PW}=1.06 \mathrm{~mm} ; \mathrm{EL}=3.3 \mathrm{~mm} ; \mathrm{EW}=1.1 \mathrm{~mm}$. Other paratype o: length $4.5 \mathrm{~mm}$.

Variability: The two female paratypes have yellow genae and reddish-brown clypeus.

Differential diagnosis: Plectonotum leymebamba sp. nov., resembles $P$. oxapampa sp. nov., and $P$. bicoloricolle sp. nov., by the pronotal bead. It differs from these two other species by the mostly black colour pattern, thicker antennae, subseriate elytral punctation and the aedeagus shape.

Etymology: Specific name refers to Leymebamba village, close to the type-locality. Noun in apposition.

Natural history: Collected by beating shrubs, on the edge of the road in the morning.

\section{Plectonotum luteipes sp. nov.} (Figs. 14, 37, 73-74, 106, 119)

Type material: Holotype ơ (MUSM): Peru, Amazonas, provincia de Chachapoyas, $25 \mathrm{~km}$ E of Balsas, flowering

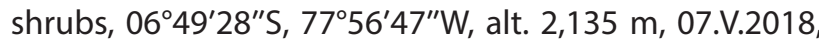
leg. R. Constantin. Paratypes: $20^{\prime \prime}, 3$, same locality and same date, leg. R. Constantin. Holotype and two paratypes deposited in the collection of the MUSM, other paratypes preserved in author's collection (CCo).

Description: Holotype. Length $3.2 \mathrm{~mm}$. Head black, genae and frons yellow between eyes and in front of the antennal sockets. Prothorax, elytra and abdomen black. Antennae black, the first two antennomeres yellow each with a brown patch on their dorso-lateral face. Labial and maxillary palpi brown, the first joint yellow. Coxae, trochanters and femora yellow, except a black mark on femoral apex, tibiae and tarsi brown except the yellow basal third of the tibiae. Head 0.77 times as wide as the pronotum, the clypeus protruding. Eyes developed, bulging, the interocular space 0.61 times as wide as the head. Frons flattened between the eyes, longitudinally de- 

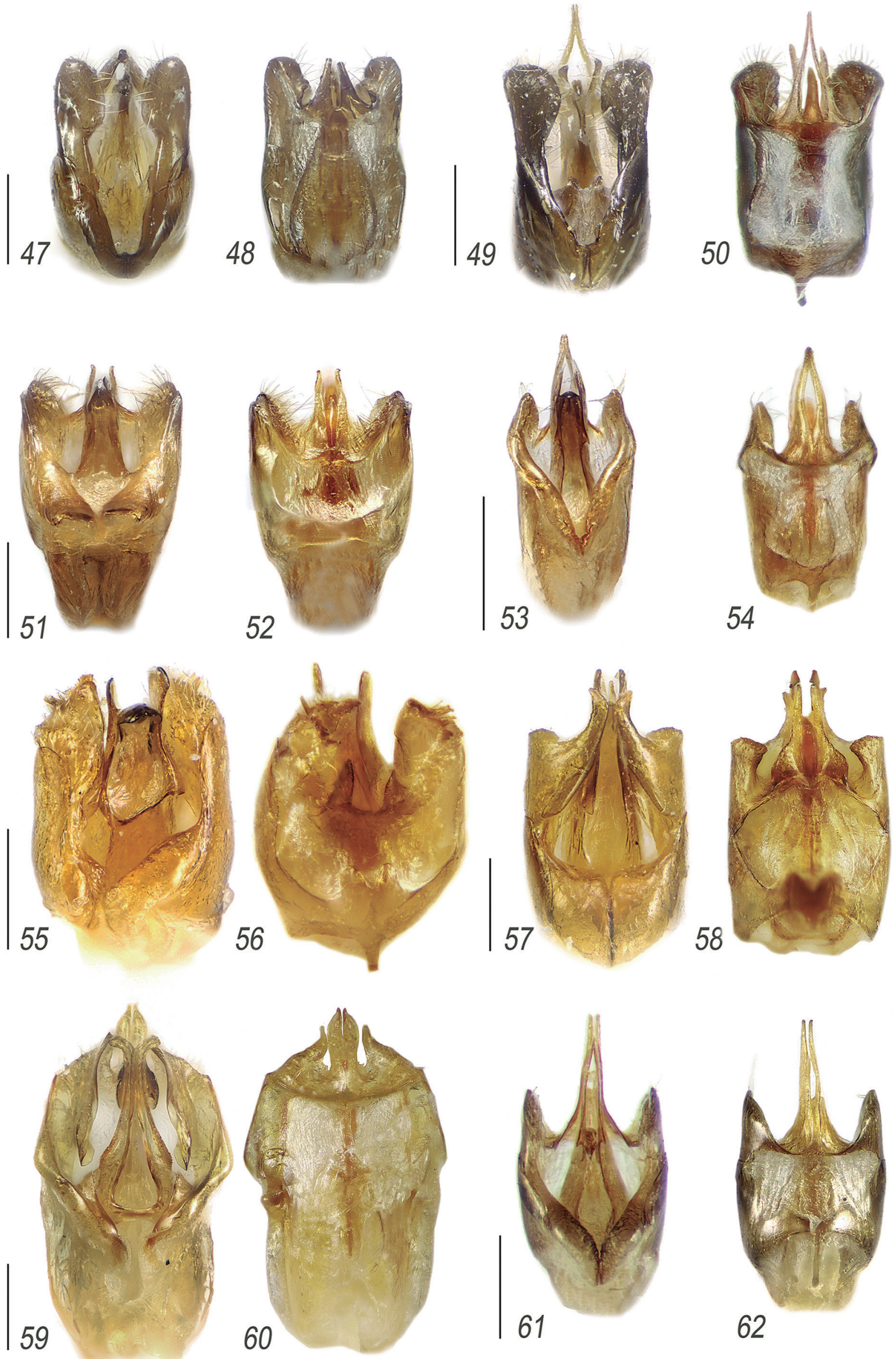

Figures 47-62. Plectonotum species, aedeagus (dorsal, ventral). (47-48) Plectonotum altomayo sp. nov.; (44-50) P. amazonas sp. nov.; (51-52) P. bicoloricolle sp. nov.; (53-54) P. carpish sp. nov.; (55-56) P. celendin sp. nov.; (57-58) P. costae sp. nov.; (59-60) P. howdeni Wittmer; (61-62) P. huariaca sp. nov. Scale bars: $0.2 \mathrm{~mm}$. 

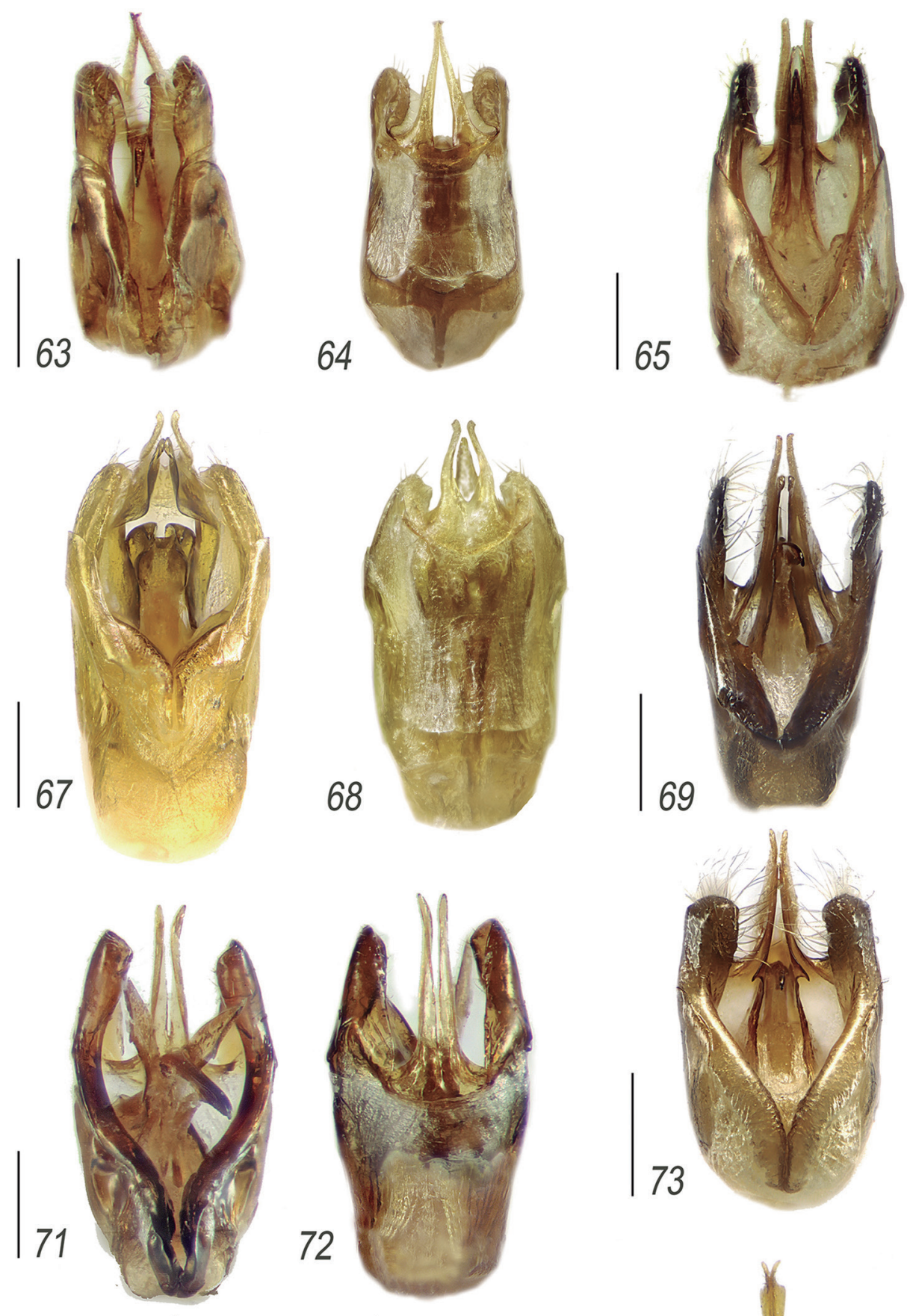

66
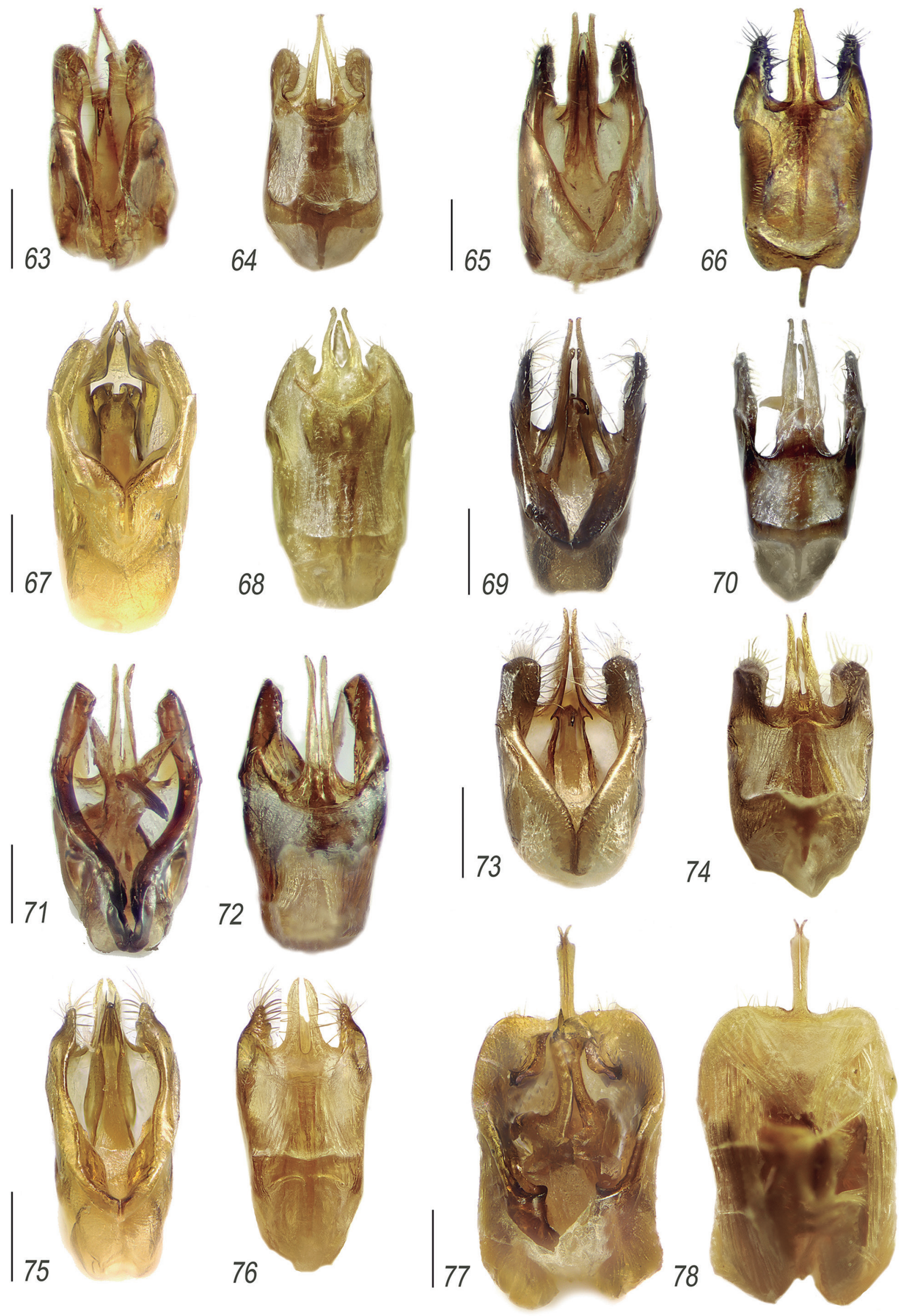

Figures 63-78. Plectonotum species, aedeagus (dorsal, ventral). (63-64) Plectonotum huscaran sp. nov.; (65-66) P. huertoae sp. nov.; (67-68) P. inca Wittmer; (69-70) P. leymebamba sp. nov.; (71-72) P. Iongissimum (Pic); (73-74) P. luteipes sp. nov.; (75-76) P. martinezi Wittmer; (77-78) P. neoruficolle nom. nov. Scale bars: 0.2 mm. 
pressed on the midline and with two oblique ridges behind the antennal sockets. Mandibles slender, with short apical denticle and slightly crenulate inner edge. Temples short, strongly narrowing backwards. Cephalic surface smooth, feebly shiny, thinly punctate, with recumbent yellowish setae. Antennae as long as the body, the first two antennomeres smooth, the following parallel sided, covered with semi-erected brown setae. Pronotum 1.5 times wider than long, transversally convex with a small discal depression. Front edge straight, rear edge feebly arched, lateral edge slightly converging towards the front with a short shiny bead and an emargination in front of the rectangular basal corners. Pronotal surface shiny, thinly punctate, the punctation 1.5 times smaller than the intervals. Elytra 3 times longer than combined width at the base, markedly rugulose punctate, covered with long, recumbent yellow setae. Abdomen with tergite IX apically triangular and medially notched; sternite IX as long as wide, the apical edge rounded. Aedeagus: tegmen with the apex of the lateral lobes bearing many long setae on posterior side; apico-ventral apophysis dorsally recurved as also the long lateral sclerites; lateral sclerites slender, with an obtuse tooth at mid-length, ventrally recurved at their tip; median lobe tapered.

Dimensions of the holotype: $\mathrm{TL}=3.2 \mathrm{~mm} ; \mathrm{AL}=3.1 \mathrm{~mm}$; $\mathrm{HW}=0.75 \mathrm{~mm} ; \mathrm{IOW}=0.46 \mathrm{~mm} ; \mathrm{OL}=0.24 \mathrm{~mm}$; $\mathrm{IAW}=0.16 \mathrm{~mm} ; \mathrm{PL}=0.64 \mathrm{~mm} ; \mathrm{PW}=0.97 \mathrm{~mm}$; $\mathrm{EL}=2.7 \mathrm{~mm} ; \mathrm{EW}=0.9 \mathrm{~mm}$. Length of the antennomeres, in $\mathrm{mm}: a l=0.30$; all $=0.13$; all $=0.26$; $a \mathrm{IV}=0.31$; $a V=0.34 ; a V I=0.34 \times 0.08 ; a V I I=0.32 ; a V I I I=0.30$; $a I X=0.27 ; a X=0.23 ; a X I=0.26$. Paratypes $\sigma^{2}$ : length 3.6 and $3.7 \mathrm{~mm}$.

Paratypes o: Differ from the males by the narrower head, flatter eyes, shorter antennae, and elytra wider in the apical third. Dimensions of one paratype $\%$. $\mathrm{TL}=3.4 \mathrm{~mm} ; \mathrm{AL}=2.1 \mathrm{~mm} ; \mathrm{HW}=0.63 \mathrm{~mm} ; \mathrm{IOW}=0.40 \mathrm{~mm}$; $\mathrm{OL}=0.19 \mathrm{~mm} ; \mathrm{IAW}=0.16 \mathrm{~mm} ; \mathrm{PL}=0.58 \mathrm{~mm}$; $\mathrm{PW}=0.89 \mathrm{~mm} ; \mathrm{EL}=2.35 \mathrm{~mm}$; $\mathrm{EW}=0.84 \mathrm{~mm}$. Other paratypes $\%$ : length 3.2 and $3.8 \mathrm{~mm}$.

Differential diagnosis: Plectonotum luteipes sp. nov., is similar to $P$. inca Wittmer, 1988 , by the similar habitus, colour pattern and pronotal shape. It differs from the latter by the longer pronotal bead, the darker legs and the different aedeagus shape.

Etymology: The specific epithet refers to the peculiar colour pattern of the legs.

Natural history: Collected beating flowering shrubs of the steep slopes.

\section{Plectonotum oxapampa sp. nov. (Figs. 17, 40, 79-80, 109, 119)}

Type material: Holotype ơ (MUSM): Peru, Pasco, provincia de Oxapampa, Villa Rica, carretera de Bosque Sho'llet at km 11, 10 $41^{\prime} 32^{\prime \prime} \mathrm{S}, 75^{\circ} 18^{\prime} 11^{\prime \prime} \mathrm{W}$, alt. 2,150 m, 26.III.2017, leg. R. Constantin. Paratypes: $10^{\circ}, 29$, same locality and date as the holotype. The holotype and a female paratype deposited in MUSM, others paratypes preserved in the author's collection (CCo).

Description: Holotype. Length $3.5 \mathrm{~mm}$. Head yellow in front of the base of the antennal sockets, black behind. Pronotum, elytra and abdomen black. Pro-, meso- and metasternum yellow. Antennae black, the ventral face of the first three antennomeres yellow. Maxillary palpi brown, the first joint yellow. Legs yellow, the apex of protibiae, the apical half of mesotibiae, the apical two thirds of metatibiae and the tarsi brown. Head 0.83 times as wide as pronotum, short. Clypeus not protruding. Eyes developed, convex, bulging. Frons concave between the antennal sockets, slightly elevated just behind. Temples straight, short. Cephalic surface bright, thinly punctate on the frons and the vertex, not punctate near the eyes, with a pubescence of thin yellow setae. Antennae as long as the body, the first two antennomeres smooth, the following parallel sided, feebly warty, with brown setae. Pronotum 1.37 times wider than long, feebly convex transversally. Front edge right, rear edge arched and laterally sinuous, lateral edge rounded with the front margin, the bead long and narrow. Pronotal surface shiny, slightly bumped at the base, the punctation thin, sparse, the punctations twice smaller than the interval. Elytra 2.9 times longer than combined width at the base, the punctation rugulose, irregularly disposed and wrinkled, covered with long yellow setae. Aedeagus: tegmen short, with apico-ventral apophysis short and a pair of additional internal foliaceous lamellae; lateral sclerites basally broad and dorsally recurved; median lobe thick and short.

Dimensions of the holotype: $\mathrm{TL}=4.0 \mathrm{~mm} ; \mathrm{AL}=4.0 \mathrm{~mm}$; $\mathrm{HW}=0.8 \mathrm{~mm} ; \mathrm{IOW}=0.41 \mathrm{~mm} ; \mathrm{OL}=0.32 \mathrm{~mm}$; $I A W=0.1 \mathrm{~mm} ; \mathrm{PL}=0.7 \mathrm{~mm} ; \mathrm{PW}=0.96 \mathrm{~mm} ; \mathrm{EL}=2.95 \mathrm{~mm}$; $\mathrm{EW}=1.03 \mathrm{~mm}$. Length of the antennomeres, in $\mathrm{mm}$ : al $=0.3$; all $=0.11 ;$ all $=0.35 ;$ alV $=0.4 ; a V=0.46$; $a V I=0.46 ; a V I I=0.43 ; a V I I I=0.4 ; a I X=0.35 ; a X=0.33$; $a X I=0.32$. Paratypes or: length $3.6-4.4 \mathrm{~mm}$.

Paratypes 9 : Differs from the males by the smaller eyes, the narrower head, and shorter antennae. Dimensions of a paratype . $\mathrm{TL}=4.0 \mathrm{~mm} ; \mathrm{AL}=2.5 \mathrm{~mm} ; \mathrm{HW}=0.66 \mathrm{~mm}$; $\mathrm{IOW}=0.37 \mathrm{~mm} ; \mathrm{OL}=0.26 \mathrm{~mm} ; \mathrm{IAW}=0.14 \mathrm{~mm}$; $\mathrm{PL}=0.62 \mathrm{~mm} ; \mathrm{PW}=0.97 \mathrm{~mm} ; \mathrm{EL}=3.05 \mathrm{~mm} ; \mathrm{EW}=1.06 \mathrm{~mm}$. Other paratype + : length $4.7 \mathrm{~mm}$.

Differential diagnosis: Plectonotum oxapampa sp. nov., is similar to $P$. inca Wittmer, 1988. It differs from the latter in the singular colour scheme of the head, and the peculiar appendages of the male tegmen.

Etymology: The specific epithet is related to the provincial name of the type locality. Noun in apposition.

Natural history: Collected beating shrubs along the road to Bosque Sho'llet. 


\section{Plectonotum rubrithorax sp. nov. (Figs. 19, 42, 83-84, 111, 119)}

Type material: Holotype ơ (MUSM): Peru, Huanuco, provincia de Leoncio Prado, 40 km NE de Tingo Maria, Abra

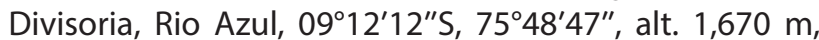
04.IV.2015, leg. R. Constantin.

Description: Holotype. Length $3.5 \mathrm{~mm}$. Head black, the clypeus yellow. Pronotum orange yellow. Elytra chocolate-brown. Antennae black, the first two antennomeres yellow, the third brownish yellow. Legs orange yellow, the apical half of tibiae and the tarsi brown. Abdomen brown. Head 0.86 times as wide as pronotum, short, the clypeus not protruding. Eyes remarkably developed, broad, bulging, the interocular space only as wide as one third of head width. Frons concave between the antennal sockets. Temples short. Cephalic surface smooth, not punctate, with sparse thin yellowish setae. Antennae longer than the body, the first two antennomeres smooth, the second very minute, the following parallel sided, warty, bearing numerous erect brown setae as long as antennomere width. Pronotum 1.6 times wider than long, with angular apical edge, arched and laterally sinuous basal edge, the lateral edge with a narrow bead and an emargination in front of the basal corners. Pronotal surface shiny, without visible punctation. Elytra 2.4 times longer than combined width at the base, very thinly punctate, irregularly disposed, covered with long, thin, yellow setae. Aedeagus: tegmen with apices of lateral lobes straight and dorsally emarginated; lateral sclerites long and slender; median lobe very short.

Dimensions of the holotype: $T L=3.5 \mathrm{~mm} ; A L=4.0 \mathrm{~mm}$; $\mathrm{HW}=0.86 \mathrm{~mm} ; \mathrm{IOW}=0.3 \mathrm{~mm} ; \mathrm{OL}=0.43 \mathrm{~mm} ;$ $I A W=0.09 \mathrm{~mm} ; \mathrm{PL}=062 \mathrm{~mm} ; \mathrm{PW}=1.0 \mathrm{~mm} ; \mathrm{EL}=2.65 \mathrm{~mm}$; $\mathrm{EW}=1.1 \mathrm{~mm}$. Length of the antennomeres, in $\mathrm{mm}$ : $a l=0.29 ;$ all $=0.08 ;$ all $=0.36 ;$ alV $=0.4 ; a V=0.44 ;$ $a V I=0.45 ; a V I I=0.45 ; a V I I I=0.43 ; a I X=0.39 ; a X=0.33$; $a X I=0.35$.

Differential diagnosis: Plectonotum rubrithorax sp. nov., is similar to the Peruvian species P. neoruficolle nom. nov., by the similar habitus and colour pattern. It differs from the latter by the concave frons, broader eyes, longer antennae, narrower pronotal bead and aedeagus shape.

Etymology: The specific epithet refers to the peculiar pronotal colouration.

Natural history: Collected beating shrubs and trees on the edge of a small wood.

\section{Plectonotum shipasbamba sp. nov.} (Figs. 20, 43, 85-86, 112, 119)

Type material: Holotype ơ (MUSM): Peru, Amazonas, provincia de Bongará, Shipasbamba $6 \mathrm{~km} \mathrm{NW}$, carretera de la mina, $05^{\circ} 52^{\prime} 32^{\prime \prime} \mathrm{S}, 78^{\circ} 00^{\prime} 00^{\prime \prime} \mathrm{W}$, alt. 2,370 m,
10.V.2018, leg. R. Constantin. Paratypes: 40", 3ㅇ, same locality and date as the holotype. Holotype and three paratypes deposited in the collection of the MUSM, other paratypes preserved in author's collection (CCo).

Description: Holotype. Length $4.0 \mathrm{~mm}$. Head black, the clypeus, genae and frons to the middle of the antennal sockets bright yellow. Prothorax, elytra, abdomen and legs black. Antennae black, the first two antennomeres rufous with orange yellow ventral side. Head 0.8 times as wide as pronotum, the clypeus triangularly extended. Eyes developed, bulging, the interocular space 0.58 times as wide as the head. Frons broad, flattened between the eyes with a shallow median longitudinal depression and two short oblique bumps behind the antennal sockets. Temples short, narrowing backwards. Cephalic surface smooth, densely punctate, the punctation as wide as the intervals, covered with thin pale yellowish setae. Antennae 0.82 times as long as the body, the first two antennomeres markedly punctate, the following parallel sided, dull, covered with fulvous setae. Pronotum 1.5 times wider than long, feebly longitudinally and transversally convex. Front edge slightly arched; lateral edge convex, narrowing frontwards, rounded with a bead constricted apically and a short emargination in front of the basal corners. Pronotal surface shiny, densely and distinctly punctate, the punctations slightly smaller than the intervals. Elytra 2.7 times longer than combined width at the base, the punctations strong and disposed along subregular series, irregularly disposed on the apical quarter. Elytral pubescence of long, thin, obliquely erected pale-yellow setae. Aedeagus: tegmen with apex of the lateral lobes convergent in dorsal view, forming a rhomboidal lamina with apical setae in lateral view; apico-ventral apophysis slender, with long tapered tips; lateral sclerites short, with a raised tooth at mid-length; median lobe with a narrow styliform projection.

Dimensions of the holotype: $T L=3.9 \mathrm{~mm} ; A L=3.2 \mathrm{~mm}$; $\mathrm{HW}=0.81 \mathrm{~mm} ; \mathrm{IOW}=0.47 \mathrm{~mm} ; \mathrm{OL}=0.3 \mathrm{~mm}$; $I A W=0.17 \mathrm{~mm} ; \mathrm{PL}=0.67 \mathrm{~mm} ; \mathrm{PW}=1.0 \mathrm{~mm} ; \mathrm{EL}=2.9 \mathrm{~mm}$; $\mathrm{EW}=1.06 \mathrm{~mm}$. Length of the antennomeres, in $\mathrm{mm}$ : $a l=0.31 ;$ all $=0.13 ;$ all $=0.31 ; a I V=0.33 ; a V=0.35$; $a V I=0.35 \times 0.09 ; a V I I=0.34 ; a V I I I=0.32 ; a I X=0.29$; $a X=0.26 ; a X I=0.29$. Paratypes $\sigma^{x}$ : length $3.6-4.1 \mathrm{~mm}$.

Paratypes $9:$ Differ from the males by the narrower head, smaller eyes, shorter antennae, and pronotum narrower anteriorly, with thin orange-yellow border along the basal edge. Dimensions of one paratype $9 . \mathrm{TL}=3.8 \mathrm{~mm}$; $\mathrm{AL}=2.06 \mathrm{~mm} ; \mathrm{HW}=0.67 \mathrm{~mm} ; \mathrm{IOW}=0.43 \mathrm{~mm} ;$ $\mathrm{OL}=0.27 \mathrm{~mm} ; \mathrm{IAW}=0.17 \mathrm{~mm} ; \mathrm{PL}=0.63 \mathrm{~mm}$; $\mathrm{PW}=0.96 \mathrm{~mm} ; \mathrm{EL}=2.95 \mathrm{~mm} ; \mathrm{EW}=1.0 \mathrm{~mm}$. Other paratypes o: length $3.9-4.0 \mathrm{~mm}$.

Differential diagnosis: Plectonotum shipasbamba sp. nov., is similar to $P$. leymebamba sp. nov., differing from the latter by the stronger and denser punctation of the head and pronotum, elytral punctations deeply 


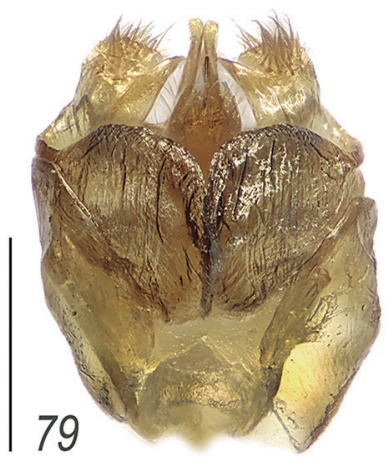

80
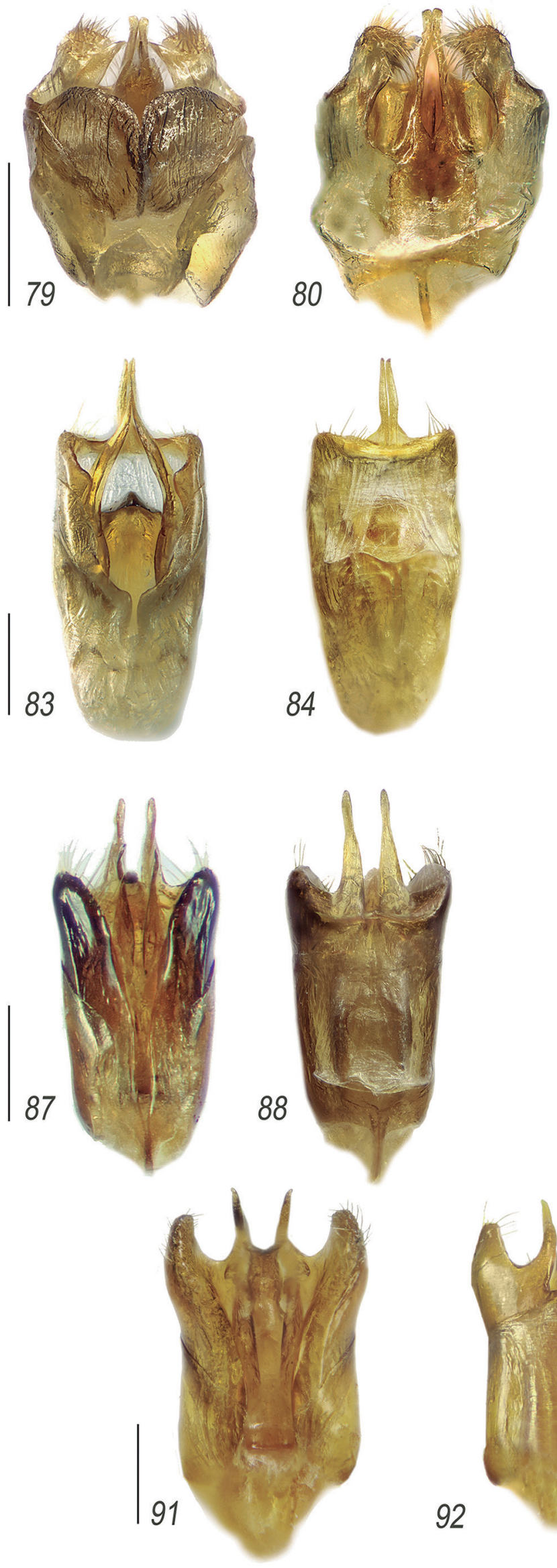

84

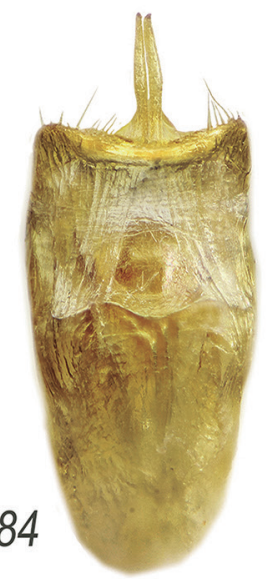

88
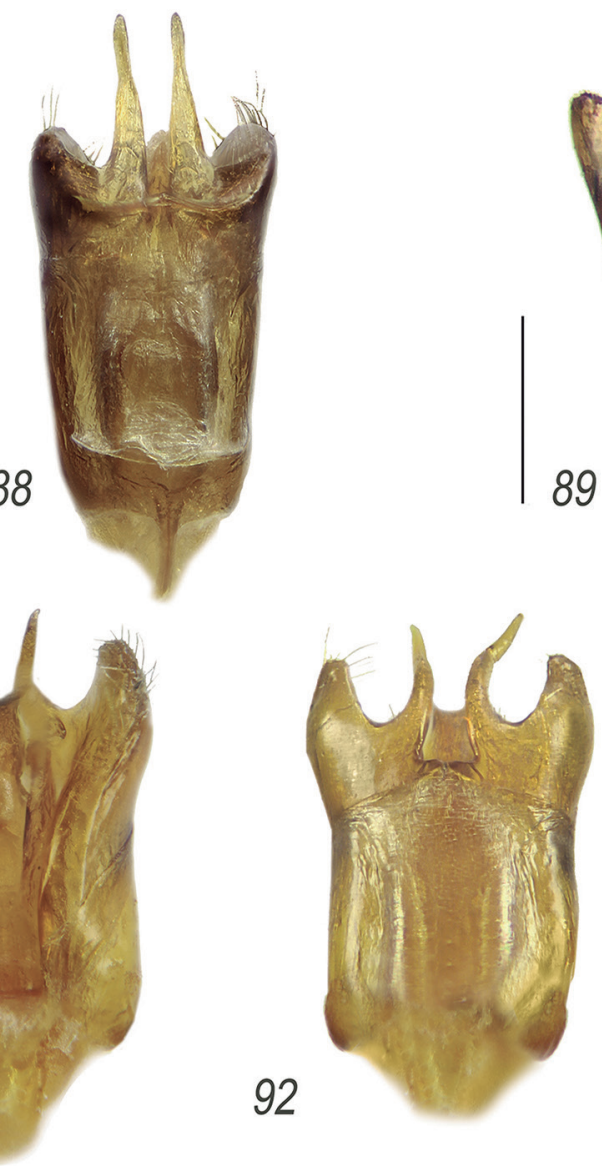
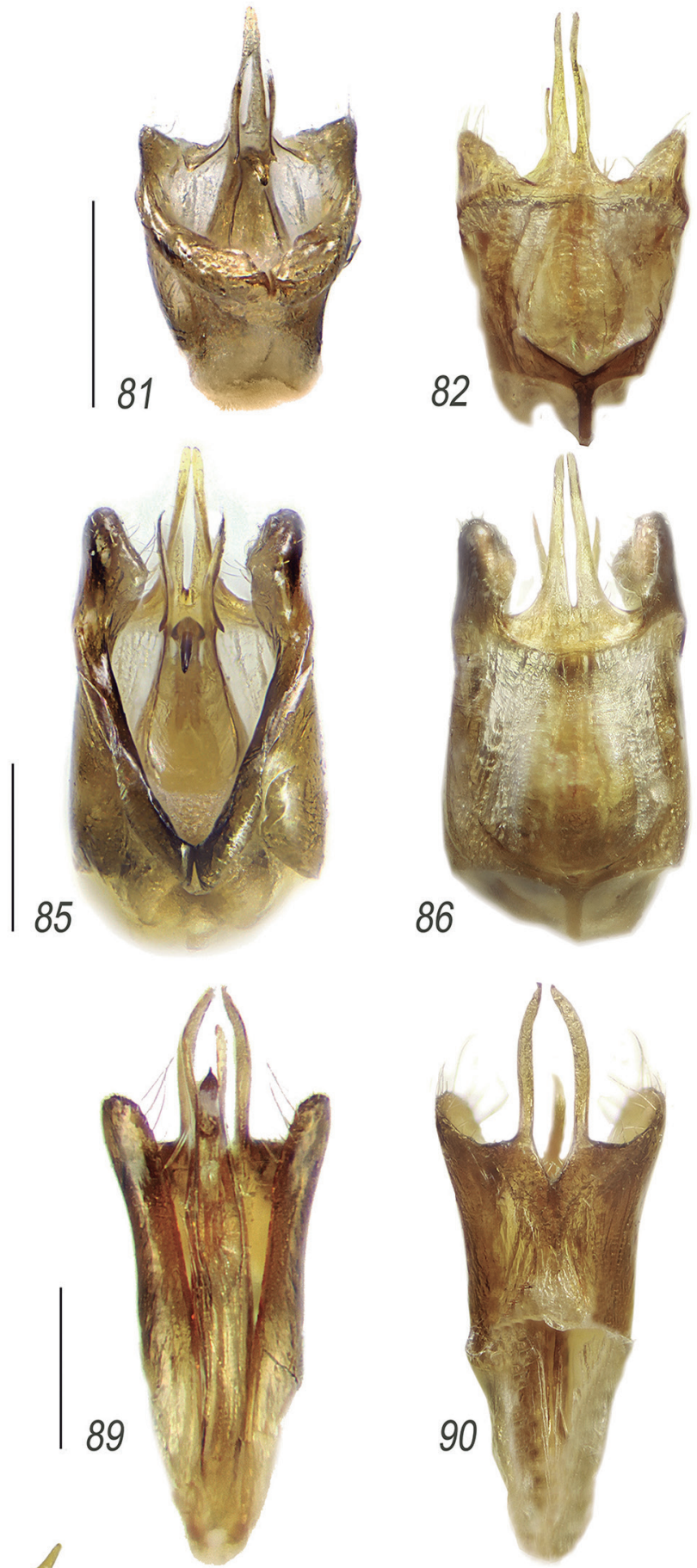

Figures 79-92. Plectonotum and Hyponotum species, aedeagus (dorsal, ventral). (79-80) Plectonotum oxapampa sp. nov.; (81-82) Plectonotum peruanum Wittmer. (83-84) P. rubrithorax sp. nov.; (85-86) P. shipasbamba sp. nov.; (87-88) Hyponotum macrocephalum sp. nov.; (89-90) H. succhabamba sp. nov.; (91-92) H. philippii (Gemminger). Scale bars: $0.2 \mathrm{~mm}$. 

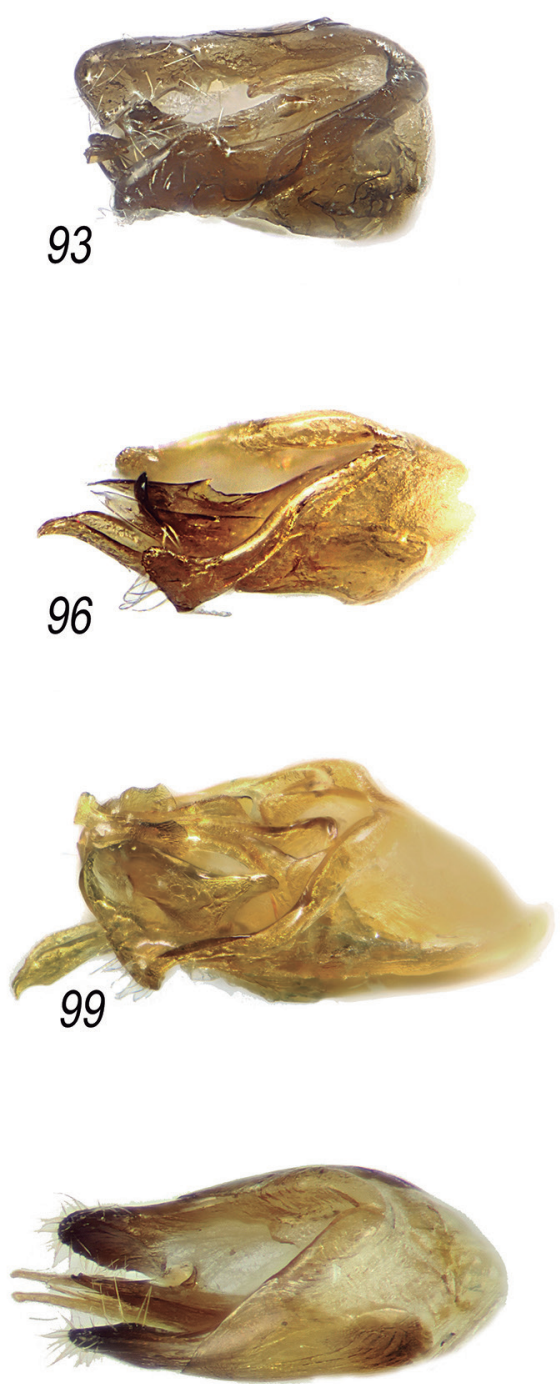

102

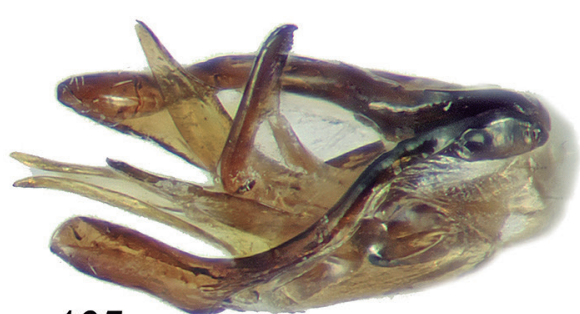

105
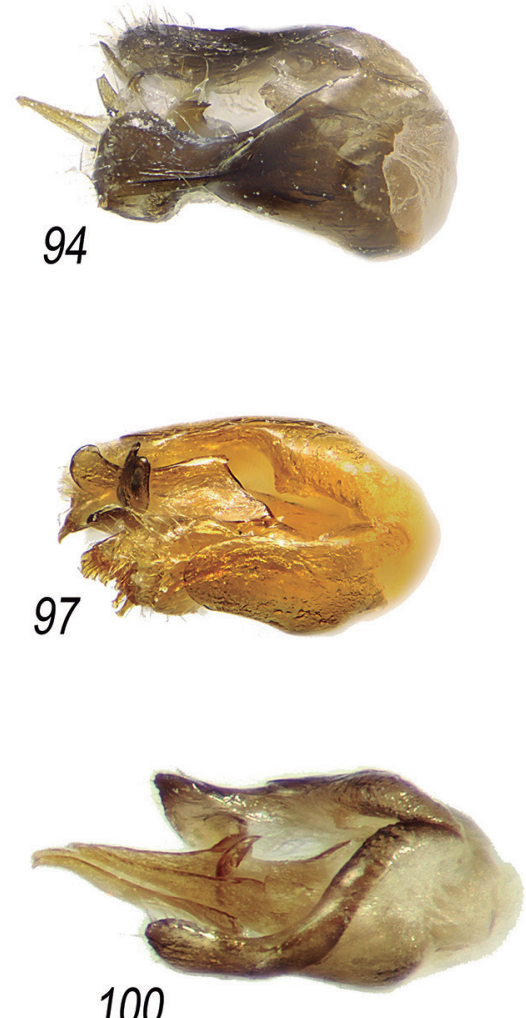

100

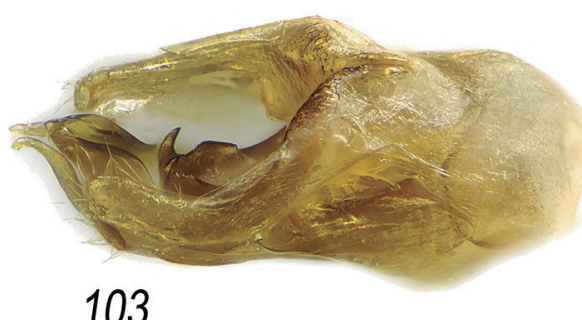

103

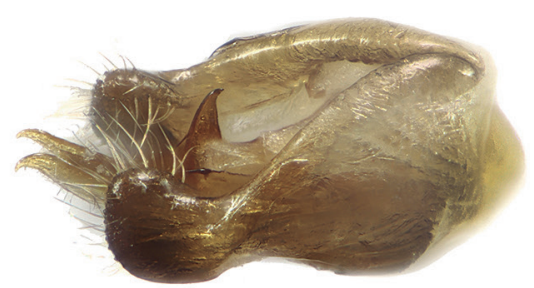

106
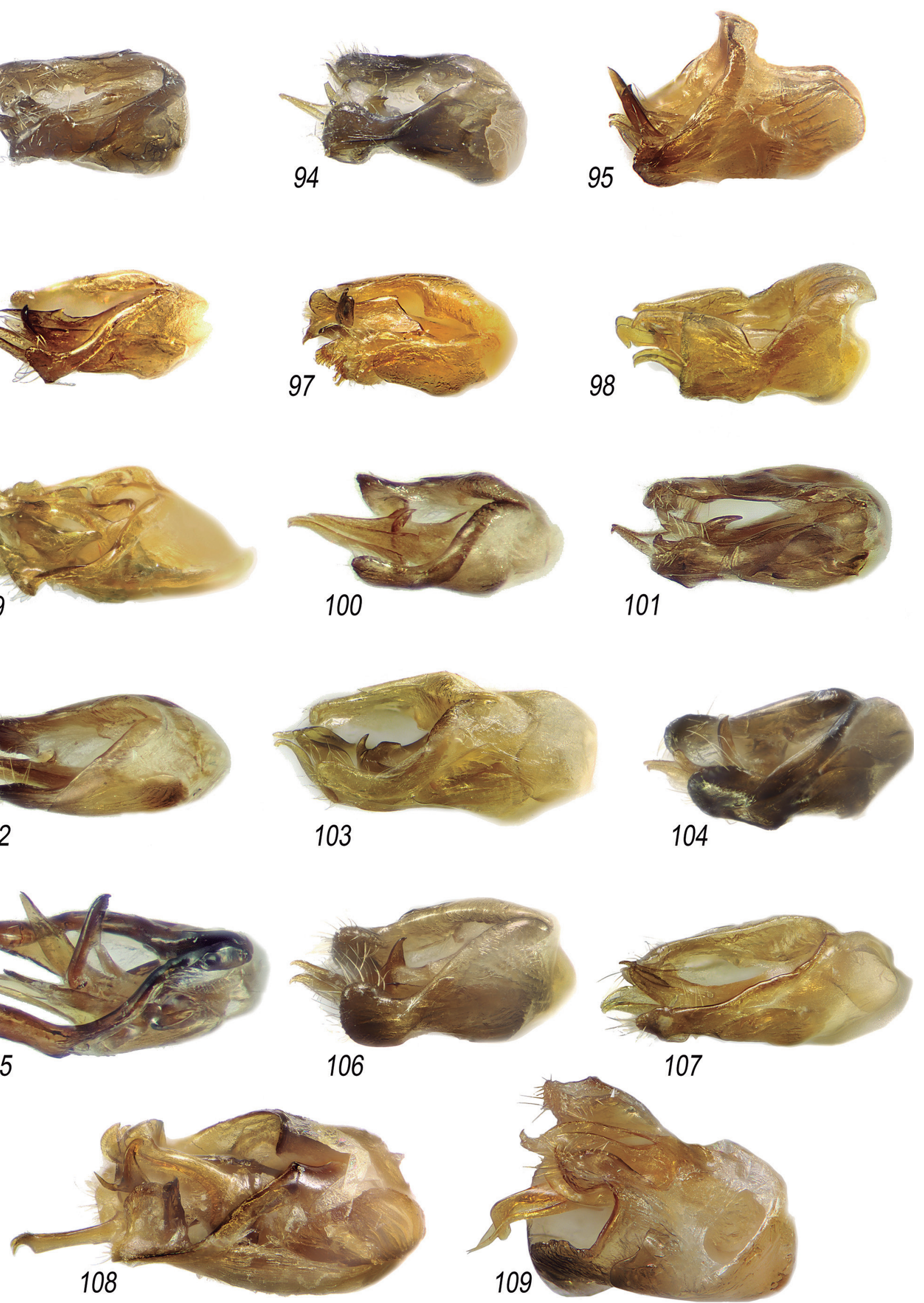

Figures 93-109. Plectonotum species, aedeagus (lateral). (93) Plectonotum altomayo sp. nov.; (94) P. amazonas sp. nov.; (95) P. bicoloricolle sp. nov.; (96) P. carpish sp. nov.; (97) P. celendin sp. nov.; (98) P. costae sp. nov.; (99) P. howdeni Wittmer; (100) P. huariaca sp. nov.; (101) P. huascaran sp. nov.; (102) P. huertoae sp. nov.; (103) P. inca Wittmer; (104) P. leymebamba sp. nov.; (105) P. longissimum (Pic); (106) P. luteipes sp. nov.; (107) P. martinezi Wittmer; (108) P. neoruficolle nom. nov.; (109) P. oxapampa sp. nov. 


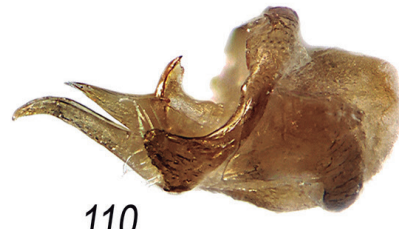

110

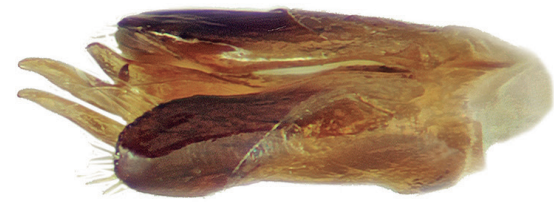

113
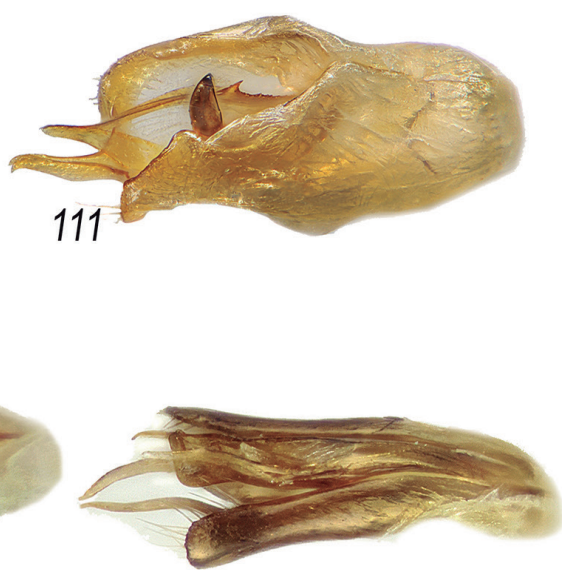

114

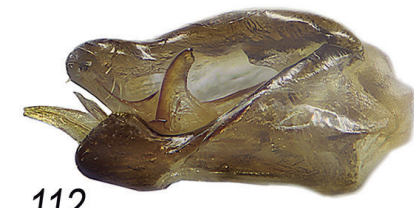

112

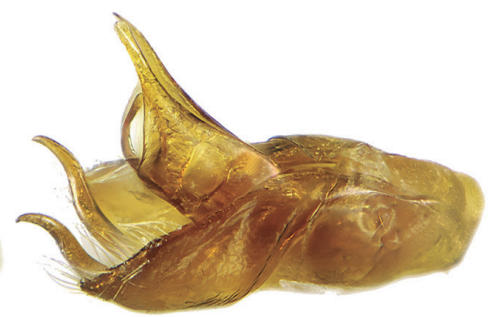

115

Figures 110-115. Plectonotum and Hyponotum species, aedeagus (lateral). (110) Plectonotum peruanum Wittmer. (111) P. rubrithorax sp. nov.; (112) P. shipasbamba sp. nov.; (113) Hyponotum macrocephalum sp. nov.; (114) H. succhabamba sp. nov.; (115) H. philippii (Gemminger).
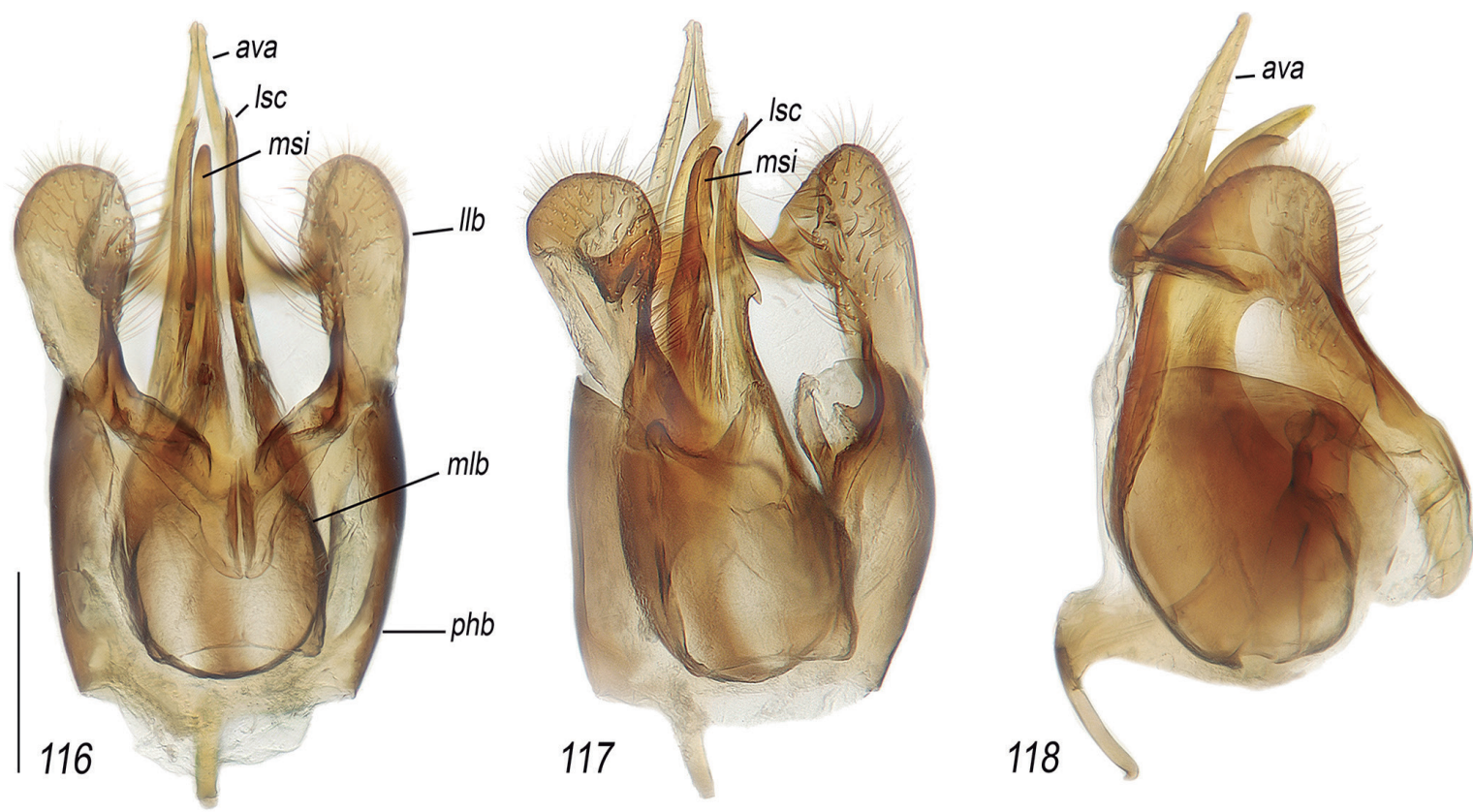

Figures 116-118. Plectonotum amazonas sp. nov., aedeagus in dorsal, dorso-lateral and lateral view (transmitted light). Abbreviations: ava = apico-ventral apophysis; Isc = lateral sclerites; llb = lateral lobes or parameres; $\mathrm{msi}=$ median sclerite of internal sac; $\mathrm{mlb}=$ median lobe; $\mathrm{phb}=$ phallobase. Scale bar: $0.2 \mathrm{~mm}$.

marked and disposed in subregular series except on the apex, and pronotal lateral edges regularly convex.

Etymology: The specific name refers to Shipasbamba village, close to the type-locality. Noun in apposition.

Natural history: Collected beating tree foliage on the hedge of an earth road to an ancient mine.

\section{Other remarks and new data on Peruvian Plectonotum}

\section{Plectonotum longissimum (Pic, 1927), designation of lectotype \\ (Figs. 13, 36, 71-72, 105, 119)}

Silis longissima Pic, 1927: 139-140.

Plectonotum longissimum, Constantin \&Chaboo, 2016: 196.
Type material examined: Known only by the laconic description of a female, just mentioning "Pérou" as type locality. The collection of Pic (MNHN) hosts a single type specimen of Silis longissima Pic which was revealed to belong to the genus Plectonotum (Constantin \& Chaboo, 2016). A closer examination confirms that it is a male specimen, presently designated as lectotype. The specimen is damaged, lacking the elytral pubescence, the apical half of abdomen and most of the tarsi. The original labels mention "Pérou, prov. Huallaga, Rio Mixiollo, 1,200 m, VII-VIII.1900, G.A. Baer (printed)"/"type"/"Silis longissima $\mathrm{n} \mathrm{sp}^{\prime \prime}$. This classical locality can be placed at the border of La Libertad, provincia de Pataz and San Martin, provincia de Tocache, on Rio Mishollo at $40 \mathrm{~km} \mathrm{~W}$ of Tocache, $08^{\circ} 10^{\prime} \mathrm{S}, 76^{\circ} 57^{\prime} \mathrm{W}$ (estimate).

Other material examined: Peru, Amazonas, provincia Bongará, Alto Shipasbamba, $05^{\circ} 47^{\prime} 33^{\prime \prime} \mathrm{S}, 78^{\circ} 03^{\prime} 28^{\prime \prime} \mathrm{W}$, 
alt. 3,030 m, 12.XII.2015, leg. W. Cassio (10" MUSM, 19 CCo); Peru, Amazonas, provincia Bongará, Shipasbamba, 05 $50^{\prime} 40.70^{\prime \prime} \mathrm{S}, 78^{\circ} 04^{\prime} 10.46^{\prime \prime} \mathrm{W}$, alt. 2,237 m, 08.XII.2018, 19, leg. Luis Perez (MUSM) - The three specimens were found strictly identical to the lectotype of Silis longissima in the antennal, pronotal and elytral characters.

Additional description of the lectotype: Black. Elytra brownish black on basal half, with transverse fulvous brown band near apexfulvous brown. Legs black, the tibiae and tarsi fulvous brown. Head 0.76 times as wide as pronotum. Eyes developed, bulging. Frons concave between the antennal sockets, flat behind. Temples short and right. Pronotum 1.42 times wider than long, thinly border all around, the lateral sides with a narrow bead, the front corners shortly bevelled, the rear corners right angled, slightly protruding. Pronotal surface irregular with a narrow prebasal furrow and two oblique hollows between the middle of disc and the rear angles. Head and pronotum with a dense, deep, raspy-rugulose punctation. Elytra distinctly elongate, four times longer than combined width basally, with trace of three narrow costae, thinly punctate, the punctation shallow, irregularly aligned. Elytral pubescence of two different kinds, with thin semi-erect yellowish setae, and also very dense and short adpressed hairs that makes a dull appearance.

Dimensions of the lectotype: $T L=6.1 \mathrm{~mm}$; $\mathrm{AL}=$ ca. $4.5 \mathrm{~mm} ; \mathrm{HW}=0.96 \mathrm{~mm} ; \mathrm{IOW}=0.56 \mathrm{~mm}$; $\mathrm{OL}=0.32 \mathrm{~mm} ; \mathrm{IAW}=0.2 \mathrm{~mm} ; \mathrm{PL}=0.84 \mathrm{~mm} ; \mathrm{PW}=1.2 \mathrm{~mm}$; $\mathrm{EL}=5.0 \mathrm{~mm} ; \mathrm{EW}=1.25 \mathrm{~mm}$. Length of the antennomeres, in $\mathrm{mm}$ : $a l=0.4 ;$ all $=0.13$; all $=0.38$; $a \mathrm{IV}=0.48$; $a V=0.48 ; a V I=0.5 ; a V I I=0.5 ; a V I I I=0.43 ; a I X=0.39$; $a X=0.36 ; a X I=$ missing.

Variability: Specimen $\sigma^{\top}$ (MUSM) (Alto Shipasbamba, $3,030 \mathrm{~m}$ ): length $6.0 \mathrm{~mm}, A L=4.8 \mathrm{~mm}$; $E L=4.8 \mathrm{~mm}$; $\mathrm{EW}=1.25 \mathrm{~mm}$. Black, the elytra with a transverse postmedian yellow strip. Aedeagus: tegmen with apical part of lateral lobes strongly emarginated, apical angles long and narrow; lateral sclerites apically wide with a preapical denticle. Specimen 9 (CCo) (Alto Shipasbamba, 3,030 m): length $6.5 \mathrm{~mm}, A L=4.5 \mathrm{~mm}$; $E L=5.2 \mathrm{~mm}$; $E W=1.5 \mathrm{~mm}$. Black head, yellow pronotum with a longitudinal median black strip and yellow elytra. It differs also from the male by the smaller and flatter eyes, longer temples, sternite VIII short and wide, and apical edge deeply incised in the middle. Specimen $\%$ (MUSM) (Shipasbamba, 2,237 m): identical to the former. Length $6.2 \mathrm{~mm}, A L=4.2 \mathrm{~mm}$; $\mathrm{EL}=5.0 \mathrm{~mm} ; \mathrm{EW}=1.5 \mathrm{~mm}$.

\section{Plectonotum peruanum Wittmer, 1967}

(Figs. 18, 41, 81-82, 110, 119)

Plectonotum peruanum Wittmer, 1967: 424.

Type material: This species was described from a male specimen labelled "43 miles East of Tingo Maria,
05.X.1954, leg. E.I. Schlinger \& E.S. Ross" (CAS), a locality which could be located in Ucayali, provincia de Padre Abad, between Abra Divisoria pass and Prevista village, $09^{\circ} 08^{\prime} \mathrm{S}, 75^{\circ} 46^{\prime} \mathrm{W}$. The single type specimen, preserved in the collection of CAS, was not available for study, but the detailed description with illustration of the male genitalia (Wittmer, 1967: 423-425) confirms the identity of the species.

Other material examined: Peru, provincia de Huánuco, túnel de Carpish, lado norte, camino viejo, 09 $43^{\prime} 12^{\prime \prime} \mathrm{S}$, $76^{\circ} 05^{\prime} 56^{\prime \prime} \mathrm{W}, 2,705 \mathrm{~m}, 15 . \mathrm{IV} .2013,20^{\prime}$, 2ㅇ, leg. R. Constantin (MUSM and CCo).

\section{Plectonotum howdeni Wittmer, 1988 (Figs. 7, 30, 59-60, 99, 119)}

Plectonotum howdeni Wittmer, 1988: 332-333.

Type material: Holotype $\sigma^{7}(\mathrm{NHMB})$ : The original label mentions “Nr. Ramon Castilla, Peru, 24.II.1972, H. \& A.

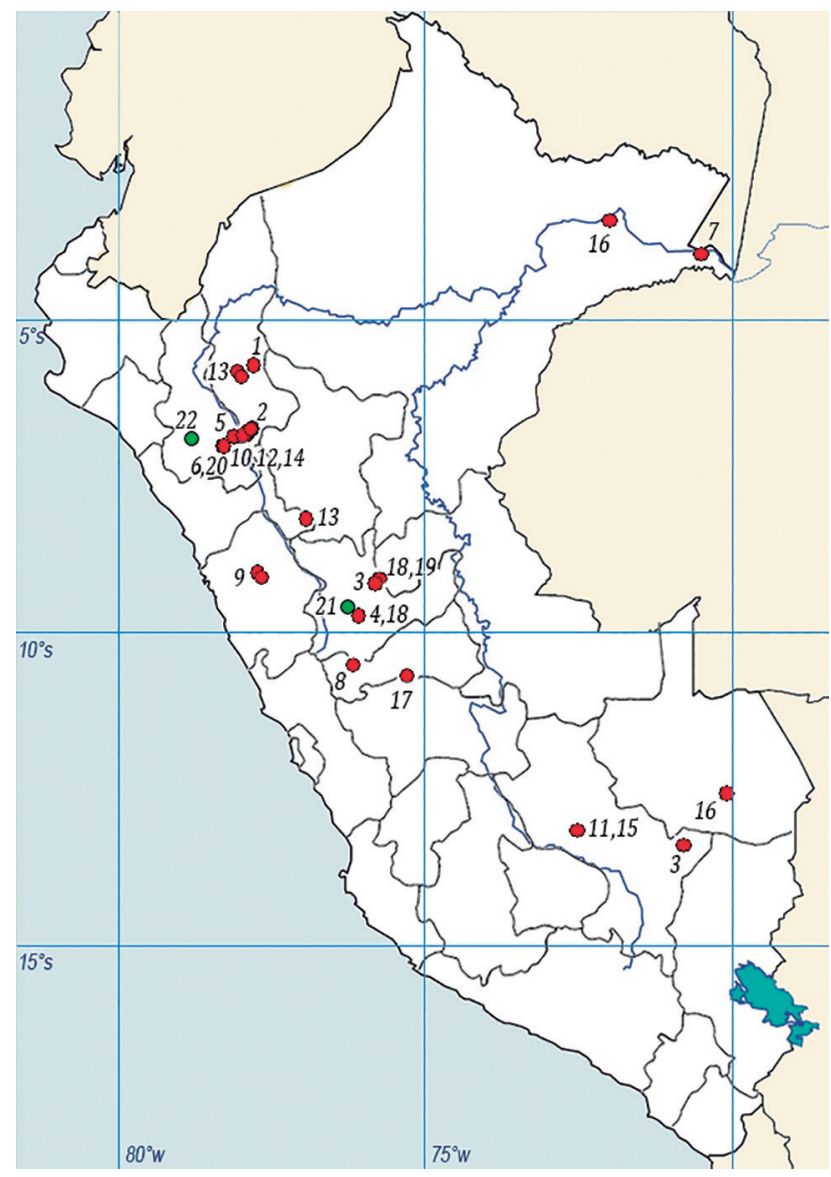

Figure 119. Map of distribution of the Peruvian Plectonotum and Hyponotum species. (1) Plectonotum altomayo sp. nov.; (2) P. amazonas sp. nov.; (3) P. bicoloricolle sp. nov.; (4) P. carpish sp. nov.; (5) P. celendin sp. nov.; (6) P. costae sp. nov.; (7) P. howdeniWittmer; (8) P. huariaca sp. nov.; (9) P. huascaran sp. nov.; (10) P. huertoae sp. nov.; (11) P. inca Wittmer; (12) P. leymebamba sp. nov.; (13) P. longissimum (Pic); (14) P. luteipes sp. nov.; (15) P. martinezi Wittmer; (16) P.neoruficollenom.nov.; (17) P.oxapampa sp. nov.; (18) P.peruanum Wittmer. (19) P. rubrithorax sp. nov.; (20) P. shipasbamba sp. nov.; (21) Hyponotum macrocephalum sp. nov.; (22) Hyponotum succhabamba sp. nov. 
Howden/ Holotypus/ Plectonotum howdeni Wittmer, det. W. Wittmer". The locality can be placed in Loreto department, ca. $03^{\circ} 54^{\prime} \mathrm{S}, 70^{\circ} 31^{\prime} \mathrm{W}$. This single specimen was dissected and illustrated in the original publication. Antennae are missing beyond the two first antennomeres.

Further illustration is presented here, after cleaning and re-mounting.

\section{Plectonotum inca Wittmer, 1988 (Figs. 11, 31, 67-68, 103, 119)}

Plectonotum inca Wittmer, 1988: 330-331.

Type material: Holotype o" (NHMB): Peru: Cuzco: “Peru, Machu Picchu, 2,000-2,400 m, 15.XII.1985, [leg.] W. Wittmer". Paratypes: 17 specimens $\sigma^{\prime \prime}$ and 9 same data as holotype (NHMB).

Illustration of habitus and male genitalia are given for comparison.

\section{Plectonotum martinezi Wittmer, 1988 (Figs. 15, 38, 75-76, 107, 119)}

Plectonotum martinezi Wittmer, 1988: 330.

Type material: Holotype ơ (NHMB): Peru: Cuzco: "Peru, Machu Picchu, 2,000-2,400 m, 15.XII.1985, [leg.] W. Wittmer". $10^{\prime \prime}$ and 19 paratypes, with same date and locality, are preserved at NHMB.

Illustration of habitus and male genitalia are given for comparison.

\section{Plectonotum neoruficolle, nom. nov. (Figs. 16, 39, 77-78, 108, 119)}

Plectonotum ruficolle Wittmer, 1988: 331, homonym of P. ruficolle Pic, 1926 (= Hyponotum ruficolle (Pic, 1926)).

Plectonotum neoruficolle Constantin, nom. nov., new name for $P$. ruficolle Wittmer, 1988.

Type material: Holotype $\sigma^{\top}$ (NHMB): Peru: Loreto, Mariscal Ramon Castilla, Estirón [near Pebas] on Rio Ampiyacu $\left[03^{\circ} 22^{\prime} \mathrm{S}, 72^{\circ} 00^{\prime} \mathrm{W}\right.$, written Rio Ampi Paco on original label], 28.III-09.IV.1970, leg. B. Malkin.
Other material examined: A single male specimen, without abdomen, was collected with UV-light trap in the department of Madre de Dios at the CICRA [12 $34^{\prime}$ S, $70^{\circ} 06^{\prime} \mathrm{W}$ ] biological station (Constantin \& Chaboo, 2016).

Pic (1926: 26) described as a new species Plectonotum ruficolle, from Chile, close to Plectonotum albocinctum Pic, 1926, published in the same page. Wittmer (1949) erected the new genus Hyponotum, designated P. albocinctum Pic as type-species and transferred P. ruficolle Pic to Hyponotum. Thus, Plectonotum ruficolle Wittmer, 1988 is a junior primary homonym of $P$. ruficolle $\mathrm{Pic}, 1926$. A new name Plectonotum neoruficolle nom. nov., is proposed for P. ruficolle Wittmer, 1988.

\section{The genus Hyponotum Wittmer, 1949}

The genus Hyponotum Wittmer, 1949 was erected as distinct from the genus Plectonotum in the reduced or absent pronotal bead, and in the simple pygidium, without apico-lateral protuberances. Wittmer designated Plectonotum albocinctum Pic, 1926 as the type species of Hyponotum, transferred P. grandicolle Pic, 1928, P. ruficolle Pic, 1926, P. violaceipenne Pic, 1928, and P. kuscheli Wittmer, 1945 to Hyponotum and described Hyponotum mimicum. Later Wittmer (1950, 1951, 1957,1980 ) described eight new species belonging to this genus and transferred others from Plectonotum. Currently, it includes 21 species (Delkeskamp, 1977; Wittmer, 1980).

The genus has never benefited from any revision. The following key is a first attempt toward an identification key, based on types and other material preserved in the collections of Wittmer (NHMB), Pic (MNHN) and some personal ones.

This genus is not really homogeneous and the species can be separated into informal groups when a particular character is considered: a first group of species, already recognized by Wittmer, includes three species with a rough head surface, with wide areolar punctation; a group with a smooth and raised periphery of the pronotum; a group with modifications of the antennomeres of the males; other species with a lateral bead of the pronotum reduced to a small tuberosity of the anterior angles or without any bead. The distribution of this genus was known only from Chile and Argentina. Recent surveys bring to light two new species from central and north Peru, described below.

\section{Key to the South American species of Hyponotum}

1. Head and pronotum dull, coarsely punctate. Lateral edges of pronotum with a short bead on the anterior part 2

- Head and pronotum thinly punctate, the punctations considerably narrower than the intervals. Pronotum without noticeable bead....................................... 4

2. Lateral edges of the pronotum arcuate; posterior angles right H. pyrocephalum (Solier, 1849)

- Lateral edges of the pronotum straight in the middle part; posterior angles obtuse H. penai Wittmer, 1980

3. Head narrowly dark spotted on the vertex or entirely red, pronotum red. H. elongatum Wittmer, 1980

- Head red with black vertex, pronotum red

4. Length over $6.0 \mathrm{~mm}$. Pronotum yellow with black marks; anterior edge arcuate, lateral edges without visible bead on the front corners ............................ 5

4. Length over $6.0 \mathrm{~mm}$. Pronotum yellow with black marks; anterior edge arcuate, lateral edges without visible bead on the front corners ............................. 5

- Length under $5.5 \mathrm{~mm}$. Pronotum red or black; distinct front angle, the front margin and the lateral margins separate, usually with a vestigial bead 
5. Pronotum orange red with a small transverse median brown patch on the disc, and two brown patches on the sides, strongly punctate, the punctations as wide as their intervals. Chile.

- Pronotum yellow with a median light-brown line and, usually, a wide lateral black border ...

6. Males: antennomeres III-IV broader than long. Elytra thinly, not seriately punctate. Argentina. H. simplicicorne (Wittmer, 1951)

- Males: antennomeres III-IV at least longer than broad

7. Males: antennomere III with subparallel sides, four times longer than broad. Chile.

.H. grandicolle (Pic, 1928)

- Males: antennomere III elongate, triangular, at most twice as long as broad.

8. Elytral punctation strong, subseriately disposed, the margins not upturned. Males: antennomere IV 1.2 times longer than III. Chile... H. chilense Wittmer, 1957

- Elytral punctation thin, not seriate, the lateral margins explanate and slightly upturned. Males: antennomere IV 1.8 times longer than III. Chile.

H. mimicum Wittmer, 1949

9. Head orange-red or yellow....... 10

- Head bicolour, mostly black 14

10. Head, pronotum and elytra testaceous yellow. Head and pronotum surface smooth. Lateral margins of pronotum wide, explanate and slightly upturned Chile... H. flavulum Wittmer, 1980

- Pronotum red or black; elytra black... 11

11. Elytra black, without yellow margins 12

- Elytra black, with thin yellow sutural and lateral edging

12. Scutellum black. Chile H. krausei (Philippi, 1861)

- Scutellum red. Chile H. solieri (Pic, 1906)

13. Length 3.8-4.5 mm. Males: antennomere IV 2.5 times longer than III. Elytra with a yellow sutural and lateral yellow border well delimited. Chile .. H. albocinctum (Pic, 1926) Length 3.0-3.5 mm. Males: antennomere IV 2 times longer than III. Elytra with suture and lateral margins paler than disc. Chile....H. liliputanum Wittmer 1950

14. Elytra yellow. Head bicolorous, black behind, yellow in front of the eyes. Pronotum yellow with a wide discal black patch. Head and pronotum strongly punctate, their intervals slightly alutaceous. Elytral punctations disposed in irregular rows. Chile... H. unifoveolatum Wittmer, 1980

- Elytra black or dark blue 15

15. Pronotum mostly or entirely red 16

- Pronotum black or blue

16. Pronotum red with two wide black patches on the anterior angles. Chile 18

- Pronotum entirely red H. collare (Solier, 1849)

17. Males: antennomeres IV-VII with emarginate postero-ventral edge. Chile. H. reedi (Pic, 1926)

- Males: antennomeres not emarginate, the sides subparallel. Chile ..H. ruficolle (Pic, 1926

18. Head as wide as pronotum. Elytra with coarse punctation (Figs. 21, 44). Peru H. macrocephalum sp. nov.

- Head narrower than pronotum. Elytra thinly punctate

19. Elytra violet blue. Males: antennomeres IV-VII with emarginate posterior-ventral edge. Head and pronotum smooth. Argentina.. H. violaceipenne (Pic, 1928)

- Elytra black. Males: antennae simple, without emarginate antennomeres.

... 20

20. Elytra thinly and irregularly punctate, with adpressed whitish pubescence. Pronotal lateral margin widest near the basal corners. Chile (Figs. 23, 46) ............

H. philippii (Gemminger, 1870)

- Elytra subseriately and coarsely punctate, with semi-erected, short and long whitish setae. Margins of the pronotum entirely furrowed (Figs. 22, 45). Peru ...

H. Hucchabamba sp. nov.

\section{Hyponotum macrocephalum sp. nov. (Figs. 21, 44, 87-88, 113, 119)}

Type material: Holotype ơ (MUSM): Peru, provincia de Huánuco, túnel de Carpish, lado norte, cabañas del camino viejo, $09^{\circ} 43^{\prime} \mathrm{S}, 76^{\circ} 06^{\prime} \mathrm{W}, 2,700 \mathrm{~m}, 28.111 .2015$, leg. R. Constantin.

Description: Holotype. Length $4.4 \mathrm{~mm}$. Head black, the front margin of the clypeus light brown. Mandibles yellow. Antennomeres I-II rusty brown with yellow ventral face, III-XI black. Pronotum, elytra and abdomen black. Legs black, protibiae yellow, tarsi brown. Head as wide as pronotum. Eyes elongate, flattened, feebly convex. Frons flat between the eyes, the surface alutaceous and dull, with dense, thin punctation and sparse, thin whitish setae. Temples long, arcuate, narrowed basally. Antennae slender, as long as three-quarters of the body. Pronotum 1.5 times wider than long. Apical edge right, basal edge feebly bisinuate, lateral edges regularly rounded, apical angles obtuse, basal angle right. Disc wide, moderately convex, separated from the border by a furrow. Lateral borders wider and more explanate than the front and rear borders. Elytra 2.8 times longer than the combined width at the base, not costate, subseriately and strongly punctate, the punctations 1.5 times wider than their intervals, covered with sparse, long (0.08-0.1 mm), whitish setae, obliquely backwards directed. Legs simples. Claws thin, without basal denticles. Abdominal sternite VIII with arched lateral edges, narrowing apically in a short tip. Aedeagus: tegmen elongate, the apico-ventral edge with two long, narrow apophyses. Lateral sclerites narrow, not denticulate. Median lobe with narrow tip.

Dimensions of the holotype: $\mathrm{TL}=4.4 \mathrm{~mm} ; \mathrm{AL}=3.1 \mathrm{~mm}$; $\mathrm{HW}=1.07 \mathrm{~mm} ; \mathrm{IOW}=0.74 \mathrm{~mm} ; \mathrm{OL}=0.31 \mathrm{~mm}$; $I A W=0.27 \mathrm{~mm} ; \mathrm{PL}=0.71 \mathrm{~mm} ; \mathrm{PW}=1.08 \mathrm{~mm} ; \mathrm{EL}=3.1 \mathrm{~mm}$; $\mathrm{EW}=1.1 \mathrm{~mm}$. Length of the antennomeres, in $\mathrm{mm}: \mathrm{al}=0.39$; 
all $=0.13 ;$ all $=0.29 ;$ alV $=0.33 ; a V=0.33 ; a V I=0.33 ;$ $a V I I=0.31 ; a V I I I=0.29 ; a I X=0.25 ; a X=0.24 ; a X I=0.27$.

Differential diagnosis: Hyponotum macrocephalum sp. nov., is similar to the Chilean H. philippii Gemminger, 1870 by the colour pattern and the shape of the pronotum, but differs by the strong subseriate elytral punctation, while $H$. philippii has a very thin and shallow elytral punctation. The very broad head with feebly convex large eyes is a singular character within the genus.

Etymology: Specific epithet refers to the peculiar broad head.

Natural history: Collected after a rain, beating the wet foliage of the trees, mainly large Asteraceae, along the ancient road of the Carpish pass, together with Plectonotum carpish sp. nov., and P. peruanum Wittmer.

\section{Hyponotum succhabamba sp. nov.} (Figs. 22, 45, 89-90, 114, 119)

Type material: Holotype ơ (MUSM): Peru, Cajamarca, provincia de Santa Cruz de Succhabamba, Pulán, Caserio de Zanja, 7855'11.7"W, 0649'17.0"S, 3,457 m, 12.IX.2012, leg. I. Medina.

Description: Holotype. Length $3.5 \mathrm{~mm}$. Head black. Mandibles fulvous yellow. Palpi brown. Antennae, pronotum and abdomen black. Elytra pitchy brown. Legs black, tibiae yellowish brown, tarsi brown. Head 0.77 times as wide as pronotum. Eyes short, convex, bulging. Frons feebly depressed between the eyes, with two small shallow oblique retro-antennal dimples. Cephalic surface dull, with marked punctation, the punctation as wide as their intervals, covered with thin yellowish, sparse setae. Temples short, narrowed basally. Antennae slender, longer than four fifths of body length. Pronotum 1.33 times wider than long. Anterior edge right, basal edge weakly arched, side edges rounded, more narrowing anteriorly than posteriorly, front and rear angles obtuse. Disc wide, moderately convex, separated from the border by a marked furrow with about fifty deep punctations. Lateral borders basally wider and more explanate than the front and rear borders. Elytra 2.55 times longer than their combined width at the base, not costate, subseriately and strongly punctate, the punctations twice wider than their intervals, covered with sparse, long $(0.1 \mathrm{~mm})$, stiff, yellowish setae, obliquely backwards directed. Legs simple, tarsi rather elongate, the metatarsi about three quarters of metatibial length, the claws thin, without basal denticles. Abdominal sternite VIII subquadrate, the apical edge truncate, laterally rounded. Aedeagus: tegmen elongate, apically wider, the apico-ventral edge with two long, narrow processes. Lateral sclerites slender, not denticulate. Median lobe with narrow tip.

Dimensions of the holotype: $T L=3.5 \mathrm{~mm} ; \mathrm{AL}=3.05 \mathrm{~mm}$; $\mathrm{HW}=0.81 \mathrm{~mm} ; \mathrm{IOW}=0.56 \mathrm{~mm} ; \mathrm{OL}=0.2 \mathrm{~mm} ; \mathrm{IAW}=0.22 \mathrm{~mm}$;
$\mathrm{PL}=0.78 \mathrm{~mm} ; \mathrm{PW}=1.04 \mathrm{~mm} ; \mathrm{EL}=2.55 \mathrm{~mm} ; \mathrm{EW}=1.0 \mathrm{~mm}$. Length of the antennomeres, in $\mathrm{mm}$ : $a \mathrm{l}=0.25$; all $=0.12$; allI = 0.25; $a \mathrm{IV}=0.32 ; a \mathrm{~V}=0.34 ; a \mathrm{VI}=0.34 ; a \mathrm{VII}=0.33$; $a V I I I=0.32 ; a I X=0.28 ; a X=0.28 ; a X I=0.28$.

Differential diagnosis: Hyponotum succhabamba sp. nov., is similar to the Chilean H. philippii Gemminger, 1870 by the size and body colour pattern and differs from the latter by the subseriately and coarsely punctate elytra, covered with semi-erected, either short or long, whitish setae and by the pronotal margins entirely furrowed.

Etymology: The specific epithet is related to the province name of the type locality.

\section{Hyponotum philippii (Gemminger, 1870) (Figs. 23, 46, 91-92, 115, 119)}

Telephorus praecox Philippi \& Philippi, 1864: 277 (Thelephorus, sic)

Cantharis praecox (Philippi \& Philippi, 1864), homonym of C. praecox Géné, 1836

Chauliognathus praecox (Philippi \& Philippi, 1864), Wittmer, 1948: 173

Hyponotum praecox (Philippi \& Philippi, 1864), Wittmer, 1957: 70

Telephorus Philippii Gemminger, 1870: 120, new name for Telephorus praecox Philippi \& Philippi, 1864

Plectonotum kuscheli Wittmer, 1945: 322

Hyponotum kuscheli (Wittmer, 1945), Wittmer, 1957: 70, synonym of $H$. praecox (Philippi \& Philippi)

Material examined: Paratype ơ (NHMB): "Stgo. [Santiago de Chile], 31.VIII.1939, paratype" [of Plectonotum kuscheIi Wittmer], leg. G. Kuschel; Santiago Chile, 07.X.1945, leg. W. Wittmer (10' NHMB); Chile, reg. IX, prov. Cautin, 30 km NE Villarica, 19-31.XII.1964, leg. L. Peña (1 $\sigma^{x}$ NHMB).

This species is distributed in central and south Chile and included here for comparison with the Peruvian species. It was described as Thelephorus praecox Philippi \& Philippi, 1864 (lapsus for Telephorus), and became a secondary homonym of Cantharis praecox Géné, 1836 when Telephorus Schaeffer, 1766, was synonymized with Cantharis Linnaeus, 1758. The taxon was then renamed as Telephorus philippii by Gemminger (1870). Wittmer (1948) transferred Cantharis praecox (Philippi \& Philippi, 1864) to Chauliognathus Hentz, 1830, probably anaware of the replacement name proposed by Gemminger (1870). Wittmer (1945) described Plectonotum kuscheli as a new species, but subsequently (Wittmer, 1957) recognized it as a synonym of Hyponotum praecox (Philippi \& Philippi, 1864). The current and valid name for the species is therefore Hyponotum philippi (Gemminger, 1870) (see ICZN, 1999, article 59.3).

\section{General remarks}

The discovery of several new species within the genus Plectonotum in Peru confirms a high diversity expect- 
ed for the genus, similarly to that observed in Ecuador. Besides the common variability of genital traits within the family Cantharidae, a striking character is the variation of the lateral beads of the pronotum, mostly identical in both sexes and very feebly variable within the members of a population and, on the contrary, showing subtle variation in shape through Andean localities.

One group of species includes Plectonotum howdeni Wittmer and P. neoruficolle nom. nov., both with broad pronotal bead, and is recorded in low altitude Amazonian region and with relatively wide distribution. A second species group comprises many Plectonotum species with narrow pronotal bead, occurring in the Andes of north Peru, especially around Cajamarca where each station revealed a different species.

These beetles live among the low humid vegetation and may be collected by beating the herbaceous vegetation or the lower branches of shrubs on the beating tray in shadowed places. Though this paper significantly increases the number of species, the Plectonotum of Peru are still feebly sampled and many other species are expected from further sampling efforts. The discovery of two species of the genus Hyponotum in northern and central Peru highlights a gap in their distribution, as the many species in Chile are hardly known further north than Santiago de Chile. Further surveys will help to better define the distribution of those two genera.

\section{ACKNOWLEDGMENTS}

I would like to thankThierry Deuve, Azadeh Taghavian, of the Muséum national d'Histoire Naturelle, Paris; Matthias Borer, Eva Sprecher-Uebersax, Isabelle Zürcher of the Naturhistorisches Museum, Basel; Diana Silva, Mabel Alvarado, Luis Figueroa of the Museo de Historia Natural de la Universidad Nacional Mayor de San Marcos, Lima (MUSM), for the large access to the collections under their care and for the loan of type material and other specimens. Special thanks are due to the whole staff of the MUSM for various help to museum access, permits applications and advice for field researches. Also to Leonard Huamán Cuespán of Tingo Maria, for assistance to survey work. Fieldwork was conducted with Peru research permit № 0122-2017-DGGSPFFS. I am indebted to my colleagues Gabriel Biffi and Michael Geiser for their critical readings and suggestions that significantly improved on the original text of the manuscript.

\section{REFERENCES}

Barbier, Y.; Rasmont, P.; Dufrêne, M. \& Sibert, J.M. 2000. Data Fauna-Flora, Guide d'utilisation. Mons, Belgique, Université de Mons-Hainaut. 106p. [1 CD-ROM].
Brancucci, M. 1980. Morphologie comparée, évolution et systématique des Cantharidae (Insecta: Coleoptera). Entomologica Basiliensia, 5: 215-388.

Constantin, R. 2008. A contribution to the genus Plectonotum Gorham, 1891, in Ecuador (Coleoptera, Cantharidae). Entomologica Basiliensia et Collectionis Frey, 30: 49-74.

Constantin, R. 2010. A contribution to knowledge of the Cantharidae (Coleoptera, Elateroidea) in Ecuador and French Guiana. Entomologica Basiliensia et Collectionis Frey, 32: 7-29.

Constantin, R. \& Chaboo, C.S. 2016. Beetles (Coleoptera) of Peru: A Survey of the Families. Cantharidae Imhoff, 1856. Journal of the Kansas Entomological Society, 89(2): 195-20.

Delkeskamp, K. 1977. Coleopterorum Catalogus Supplementa, Cantharidae. 2.ed. The Hague, DrW. Junk. Pars 165, fasc. 1, 485p.

Gemminger, M. 1870. Telephorus Philippii Gemminger In: Coleopterologische Hefte, Munchen, Carl Merhoff's Verlag. v. 6, p. 120. https://www. biodiversitylibrary.org/item/81206\#page/132/mode/1up

Gorham, H.S. 1880-1886. In: Godman, F.D. \& Salvin, 0. (Eds.). Biologia Centrali-Americana. Insecta, Coleoptera, Malacodermata (Lycidae, Lampyridae, Telephoridae, Lymexylonidae, Melyridae, Cleridae, Ptinidae, Bostrychidae, (ioidae). London, Porter. v. 3, pt 2, 372p. + 13 colour plates (Supplement: 306-307, 1885).

Gorham, H.S. 1891. Coleoptera (Continued): 44-58. In: Whymper, E. Supplementary appendix to Travels amongst the great Andes of the Equator. London, John Murray. 147p.

International Commission on Zoological Nomenclature (ICZN). 1999. International Code of Zoological Nomenclature. 4.ed. London, International Trust for Zoological Nomenclature. xxix $+306 \mathrm{p}$.

Philippi, R.A. \& Philippi, F. 1864. Beschreibung einiger neuen Chilenischen Käfer. Entomologische Zeitung, Stettin, 25: 266-284.

Pic, M. 1911. Contribution à l'étude du genre "Plectonotum" Gorham. L'Echange, 27: 174-175; 178-180.

Pic, M. 1926. Malacodermes exotiques. L'Echange, 42(424), Hors-texte: 25-28.

Pic, M. 1927. Nouveaux Coléoptères exotiques. Bulletin de la Société entomologique de France, 139-140.

Wittmer, W. 1945. Nuevos Cantharidae (Col.) (40 contribución al conocimiento de los Malacodermata neotropicos). Revista de la Sociedad Entomológica Argentina, 12: 313-326.

Wittmer, W. 1948. Notas sinonímicas y sistemáticas sobre Malacodermata (1a nota). Anales de la Sociedad Científica Argentina, 145: 167-173.

Wittmer, W. 1949. 7. Beitrag zur Kenntnis der neotropischen Malacodermata. Revista de la Sociedad Entomológica Argentina, 14: 215-222.

Wittmer, W. 1950. 9. Beitrag zur Kenntnis der neotropischen Malacodermata (Col.). Revista de Entomología, Rio de Janeiro, 21(1-2): 247-257.

Wittmer, W. 1951. Nuevos Cantharidae de la Cordillera de los Andes (Coleoptera). (11. Contribución al conocimiento de los Malacodermata neotropicales). Revista Chilena de Entomología, 1: 187-188.

Wittmer, W. 1957. Notas sobre algunos Cantharidae de Chile (1) (Coleoptera). Revista Chilena de Entomología, 5: 67-71.

Wittmer, W. 1967. 28. Beitrag zur Kenntnis der neotropischen Malacodermata (Coleoptera). Studia Entomologica (Petropolis), 10(1-4): 419-432.

Wittmer, W. 1980. 36. Beitrag zur Kenntnis der neotropischen Cantharidae (Col.). Mitteillungen der Entomologische Gesellschaft Basel, N.F., 30:62-65.

Wittmer, W. 1988. 40. Beitrag zur Kenntnis der neotropischen Fauna (Coleoptera, Cantharidae und Malachiidae). Entomologica Basiliensia, 12: 325-341. 


\section{APPENDIX}

\section{Clave para las especies peruanas de Plectonotum}

1. Longitud total superior a $6,0 \mathrm{~mm}$. Cuerpo estrecho, de color negro uniforme o con manchas amarillo pálido en el pronoto y el élitro. Cabeza y pronoto fina y groseramente punteados. Élitros con puntuación dispuesta en líneas irregulares (Fig. 13).

P. longissimum (Pic, 1927)

- Longitud total inferior a $5,0 \mathrm{~mm}$. Otros caracteres diferentes.

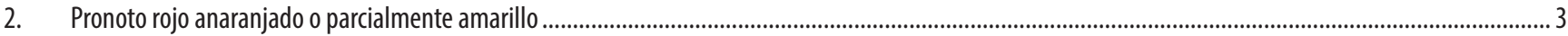

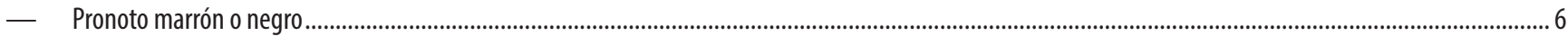

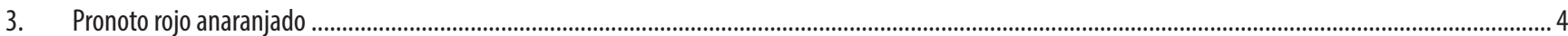

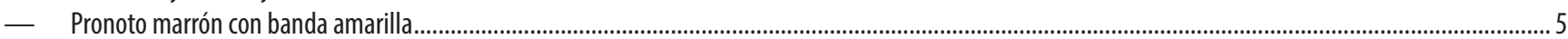

4. Reborde lateral del pronoto estrecho (Fig. 42). Frente deprimida entre los ojos ............................................................................... P. rubrithorax sp. nov.

- Reborde lateral del pronoto ancho (Fig. 39). Frente ligeramente convexa entre los ojos ...................................................................... neoruficolle nom. nov.

5. Pronoto amarillo anaranjado con una amplia banda longitudinal marrón mediana desde el borde anterior al borde posterior (Fig. 30)......

- Pronoto marrón con una amplia banda amarilla transversal en el tercio basal (Fig. 26)

P. howdeni Wittmer, 1988

6. Fémures y base de las tibias amarillas, restante de la tibia marrón. Clípeo amarillo.

P. bicoloricolle sp. nov.

- Patas uniformemente marrones o negras. Clípeo generalmente oscuro

7. Márgenes laterales del pronoto rectas en la parte media, reborde lateral corto y angosto. Antenas de color amarillo pardusco. Longitud 3,8 mm

P. inca Wittmer, 1988

- Márgenes laterales del pronoto regularmente redondeados, reborde lateral angosto. Antenas marrones con los dos primeros artejos parcialmente amarillos8

8. Cabeza y pronoto ligeramente punteados (Fig. 40). Reborde lateral del pronoto estrecho y largo alcanzando los ángulos anteriores. Longitud 3,6-4,7 mm .....

P. oxapampa sp. nov.

- Cabeza y pronoto lisos (Fig. 37). Reborde lateral del pronoto más ancho, estrechandose en dirección a los ángulos anteriores. Longitud 3,6 mm

P. luteipes sp. nov.

9. Cabeza negra, clípeo $y$ frente antes de las inserciones de las antenas enteras 0 en parte amarillas .................................................................................. 10

- Cabeza generalmente de color marrón o negro uniforme............................................................................................................................................. 12

10. Pronoto brillante, sin puntuación visible (Fig. 38). Reborde lateral del pronoto corto y estrecho.................................................... P. martinezi Wittmer, 1988

- Pronoto poco brillante, finamente punteado ... 11

11. Márgenes laterales del pronoto casi rectos, ligeramente convergentes (Fig.43). Reborde lateral del pronoto estrecho, no más ancho basalmente. Machos: antenas tan largas como los élitros. Longitud 3,6-4,1 mm

P. shipasbamba sp. nov.

- Márgenes laterales del pronoto ligeramente redondeados y convergentes (Fig. 24). Reborde lateral del pronoto apicalmente estrecho, más ancho en su parte basal. Machos: antenas más cortas que los élitros. Cabeza y pronoto usualmente micro-reticulados. Hembras: epipleura amarilla pálido....P. altomayo sp. nov.

12. Élitros fuertemente punteados ... 13

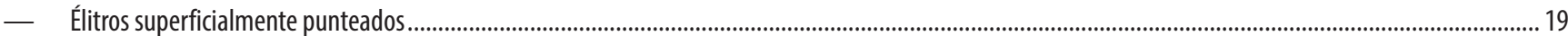

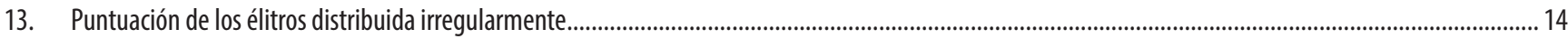

- Puntuación de los élitros dispuesta en líneas regulares 0 irregulares ..................................................................................................................... 16

14. Reborde lateral del pronoto largo y estrecho (Fig. 31). Élitros bastante cortos, 2,4 veces más largos que el ancho en su base. Hembras ápteras. (Figs. 8, 31). Longitud inferior a $3,0 \mathrm{~mm}$

P. huariaca sp. nov.

- Reborde lateral más corto y ancho. Longitud superior a 3,0 mm.

15. Reborde lateral del pronoto apicalmente más estrecho (Fig. 33). Cabeza uniforme negra 15

- Reborde lateral del pronoto con el mismo ancho en la región basal e apical (Fig. 35). Clípeo marrón. Longitud 3,9-4,5 mm...

P. huertoae sp. nov. parduscas. Longitud 3,0-3,7 mm

P. leymebamba sp. nov

P. celendin sp. nov.

- Pronoto no más ancho que la base de los élitros ....................... 17

17. Reborde lateral del pronoto arredondeado, dilatado centralmente, estrechándose apicalmente y basalmente (Fig. 29) P. costae sp. nov.

- Reborde lateral recto y estrecho. 18

18. Disco del pronoto medialmente deprimido, densamente y fuertemente punteado (Fig. 25). Élitros alargados. Longitud total superior a $4,0 \mathrm{~mm}$

P. amazonas sp. nov. Disco del pronoto convexo, finamente punteado (Fig. 32). Élitros más cortos. Longitud total 3,0-4,1 mm

P. huascaran sp. nov.

19. Disco del pronoto convexo, micro-reticulado, fina y densamente punteado (Fig. 41). Cabeza, pronoto y élitros negros. Machos: antenas más cortas que la longitud combinada del pronoto y élitro...

P. peruanum Wittmer, 1967

- Disco del pronoto débilmente convexo, brillante, fina y escasamente punteado (Fig. 27). Cabeza negra pronoto y élitros marrón rojizo. Machos: antenas alargadas, tan largo que la longitud combinada del pronoto y élitro P. carpish sp. nov. 


\section{Clave para las especies suramericanas de Hyponotum}

1. Cabeza y pronoto sin brillo, con puntos groseros. Bordes laterales del pronoto con un reborde estrecho anteriormente ....................................................... 2

- Cabeza y pronoto finamente puntuados, cada punto mucho más estrecho que los intervalos entre sí. Pronoto sin reborde perceptible................................... 4

2. Bordes laterales del pronoto arredondados; ángulos posteriores rectos H. pyrocephalum (Solier, 1849)

- Bordes laterales del pronoto rectos en la parte media; ángulos posteriores obtusos

H. penai Wittmer, 1980

3. Cabeza completamente roja, o roja con manchas oscuras en el vertex

4. Cabeza roja con vertex negro........................................................................................................................................ H. elongatum Wittmer, 1980 en los ángulos anteriores.

- Longitud total menor a 5,5 mm. Pronoto rojo o negro, con ángulo anterior distinto, el margen anterior y el margen lateral separados, generalmente con un reborde vestigial

5. Pronoto rojo anaranjado con una pequeña mancha marrón mediana transversal en el disco y dos manchas marrones en los lados, fuertemente punteado, distancia entre los puntos igual al ancho de un punto. Chile H. trisignatum (Pic, 1926)

- Pronoto amarillo con una banda mediana de color marrón claro y generalmente un borde ancho de color negro

6. Machos: antenómeros III-IV más anchos que largos. Élitros con puntuación fina, no alineada. Argentina. H. simplicicorne (Wittmer, 1951)

- Machos: antenómeros III-IV más largos que anchos.

7. Machos: antenómero III con lados subparalelos, cuatro veces más largo que ancho. Chile

H. grandicolle (Pic, 1928)

- Machos: antenómero III triangular, máximo dos veces más largo que ancho . .8

8. Puntuación de los élitros fuerte, dispuesta en líneas irregulares, las márgenes no elevadas. Machos: antenómero IV 1,2 veces más largo que el III. Chile.......... H. chilense Wittmer, 1957

- Puntuación de los élitros fina, no ordenada, las márgenes laterales anchas y ligeramente elevadas hacia arriba. Machos: antenómero IV 1,8 veces más largo que el III. Chile

H. mimicum Wittmer, 1949

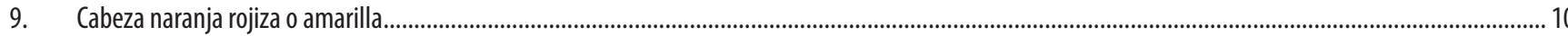

- Cabeza negra.............................................................................................................................................................................................. 14

10. Cabeza, pronoto y élitros testáceo-amarillo. Cabeza y pronoto lisos. Márgenes laterales del pronoto anchas, aplanadas y ligeramente elevadas. Chile.

H. flavulum Wittmer, 1980

- Pronoto rojo o negro. Élitros negros.

11. Élitros negros sin márgenes amarillas .12

- Élitros negros con sutura fina y bordes laterales amarillos... 13

12. Escutelo negro. Chile H. krausei (Philippi, 1861)

- Escutelo rojo. Chile H. solieri (Pic, 1906)

13. Longitud total 3,8-4,5 mm. Machos: antenómero IV 2,5 veces más largo que el III. Élitros con una sutura amarilla y borde amarillo lateral bien delimitado. Chile. H. albocinctum (Pic, 1926)

— L Longitud 3,0-3,5 mm. Machos: antenómero IV dos veces más largo que el III. Élitros con sutura y margen lateral más pálido que el disco. Chile

H. liliputanum Wittmer 1950

14. Élitros amarillos. Cabeza bicolor, negra posterior a los ojos, amarilla adelante de los ojos. Pronoto amarillo con una amplia mancha negra en el disco. Cabeza y pronoto fuertemente punteados, sus intervalos ligeramente micro-reticulados. Puntuación de los élitros dispuestas en filas irregulares. Chile.

H. unifoveolatum Wittmer, 1980

- Élitros negros 0 azul oscuro . .15

15. Pronoto mayormente rojo ... 16

- Pronoto negro o azul ... 18

16. Pronoto con dos manchas negras anchas en los ángulos anteriores. Chile. H. collare (Solier, 1849)

- Pronoto enteramente rojo

17. Machos: antenómeros IV-VII con borde postero-ventral emarginado. Chile

- Machos: antenómeros no emarginados, con lados subparalelos. Chile

18. Cabeza tan ancha como el pronoto. Élitros con puntuación grosera (Figs. 21, 44). Perú H. reedi (Pic, 1926)

- Cabeza más estrecha que el pronoto. Élitros finamente punteados H. ruficolle (Pic, 1926)

19. Élitros violín azul. Machos: antenómeros IV-VII con borde posterior-ventral emarginado. Cabeza y pronoto liso. Argentina H. macrocephalum sp. nov.

20. Élitros delgados y confusamente punteados, con pubescencia blanquecina curvada. Margen lateral del pronoto más ancho cerca de los ángulos basales (Fig. 23, 46). Chile. H. philippii (Gemminger, 1870)

- Élitros punteados con punteos gruesos dispuestos en filas irregulares, la pubescencia blanquecina semi-erecta, corta 0 larga. Margen del pronoto completamente surcada a su alrededor. (Figs. 22, 45) Perú H. succhabamba sp. nov. 